\title{
Lazaroa
}

ISSN-e 1988-3307

\section{Plant communities supported by the geological setting: the case history of the Isole dei Ciclopi (east Sicily)}

\author{
Saverio Sciandrello ${ }^{1}$, Pietro Minissale ${ }^{2} \&$ Giovanni Sturiale $^{1}$
}

Received 14 October 2016 / Accepted 3 May 2017

\begin{abstract}
This paper provides an update inventory of the vascular flora and a framework of the plant communities of the Isole dei Ciclopi (Acicastello, Catania) taking into account their geological setting. A total of 111 phytosociological relevés were performed in the period 2015-2016. The plant communities has been analyzed using WPGMA and Euclidean distance classification. The study area preserves interesting plant-communities, mainly represented by shrubs vegetation (Oleo-Ceratonion siliquae and Pruno-Rubion ulmifolii), rocky coast communities (Crithmo-Staticion), cliff vegetation (Anthyllidion barbae-jovis), halo-nitrophilous vegetation (Pegano-Salsoletea), spring-flowering meadows (Frankenion pulverulentae) and nitrophilous communities (Allion triquetri and EchioGalactition tomentosae). The vegetation analysis allow the identification of twelve vegetation types and also the reconstruction of three vegetation series. The collected data have been organized in a GIS and the following thematic maps have been produced: vegetation map, habitats map (according to the 92/43/EEC Directive). According to directive $92 / 43 / \mathrm{EU}$, only three habitat types were delimited through the phytosociological assessment of the plant communities. The flora of the investigated area consists of 102 taxa. The majority of the taxa represented in the life form spectrum are therophytes and hemicryptophytes. From a chorological point of view, the Mediterranean element outweighs the rest, followed by the most diverse group of widespread taxa. Furthermore a detailed geological investigation was carried out and a geological sketch map was performed. The comparison between the vegetation and geological maps shows a good correlation, mostly regarding the distribution of the plant communities onto the different types of substrata.
\end{abstract}

Keywords: flora, habitats, conservation, vegetation and geological maps, Sicily, Mediterranean islets.

\section{[es] La vegetación y su relación con el sustrato geológico: el caso de Isole dei Ciclopi (este de Sicilia, Italia)}

Resumen. Se presenta un inventario actualizado de la flora vascular y de las comunidades vegetales de la Isole dei Ciclopi (Acicastello, Catania) teniendo en cuenta su situación geológica. Se realizaron un total de 111 inventarios fitosociológicos en el período 2015-2016. Las comunidades de plantas se han analizado mediante clasificaciones (WPGMA, distancia euclídea). El área de estudio conserva interesantes comunidades vegetales, representadas principalmente por vegetación arbórea (Oleo-Ceratonion siliquae y Pruno-Rubion ulmifolii), comunidades costeras rocosas (Crithmo-Staticion), vegetación de acantilados (Anthyllidion barbae-jovis), vegetación halo-nitrófila(Pegano-Salsoletea), comunidades terofíticas de carácter halófilo (Frankenion pulverulentae) y comunidades nitrófilas (Allion triquetri y Echio-Galactition tomentosae). El análisis de la vegetación ha permitido la identificación de doce tipos de comunidades y la reconstrucción de tres series de vegetación. Los datos recogidos se han organizado en un SIG y se han elaborado los siguientes mapas temáticos: mapa de vegetación, mapa de hábitats (Directiva 92/43/CEE). De acuerdo con la Directiva 92/43/CEE, sólo tres tipos de hábitats fueron delimitados a través de la evaluación fitosociológica de las comunidades vegetales. La flora de la zona investigada se compone de 102 taxones, la mayoría terofitos y hemicriptofitos. Desde el punto de vista corológico, el elemento mediterráneo supera al resto, seguido por el grupo más diverso de taxones de amplia distribución. Además, se llevó a cabo una detallada investigación geológica y se realizó un mapa preliminar geológico. La comparación entre la vegetación y los mapas geológicos muestra una buena correlación, principalmente en lo que respecta a la distribución de las comunidades vegetales en los diferentes tipos de sustratos.

Palabras clave: Flora, hábitats, conservación, vegetación, mapas geológicos, Sicilia, islotes Mediterráneos.

Centre for the Conservation and Management of Nature and Agroecosystems (CUTGANA), University of Catania, Via Santa Sofia 98. I-95123 Catania.

2 Department of Biological, Geological and Environmental Sciences, University of Catania, Via A. Longo 19. I-95125 Catania. 


\section{Introduction}

The Mediterranean islands generally represent very important areas for the occurrence of several endemic or rare vascular plant species (Médail \& Quézel, 1999; Kallimanis \& al., 2010). Cyclops Islands ("Isole dei Ciclopi" in Italian), close to the Sicilian coast, in the Ionian Sea, are so small (about $2 \mathrm{Ha}$ ), but famous in the world because connected to one of the most known Greek myths: Odysseus and the Cyclops, narrated by Homer in his Odyssey. Moreover they represent the products of the oldest Etnean volcanic phase occurred about 500000 years ago (Branca \& al., 2011; De Beni \& al., 2011). Anyway as islets, they have a biogeographical interest to be compared mainly with the numerous small islands around Sicily. In the past the circum-Sicilian islets, attracted the interest of several botanists, which have mainly investigated the vascular flora (Lojacono-Pojero, 1878; Sommier, 1906, 1907, 1922; Francini \& Messeri, 1956; Albo, 1959; Di Martino, 1958, 1962, 1963; Di Martino \& Trapani, 1964, 1967, 1968; Catanzaro, 1965, 1984, 1992; Ferro \& Furnari, 1968; Di Martino \& Perrone, 1970, 1974; Ferro \& Furnari, 1970; Di Benedetto, 1973; Brullo \& Di Martino, 1974; Brullo \& al., 1977; Brullo \& Marcenò, 1983; Longhitano, 1983; Bartolo \& al., 1990; Brullo \& Siracusa, 1995; Siracusa, 1995; Troìa, 1998; Gianguzzi, 1999; Mazzola \& al., 2001; Pasta \& Lo Cascio, 2002; Pasta, 2004; Minissale \& al., 2005; Gianguzzi \& al., 2006; Romano \& al., 2006; Pasta, 2001; Lo Cascio \& Pasta, 2012; Pasta \& al., 2014; Minissale \& Sciandrello, 2017).

Regarding the Isole dei Ciclopi the first floristic collections were carried out by Nicotra (1893) and Zodda (1911), but the first vascular flora check-list can be attributed to Musmarra (1941) and recently to Siracusa (1995), while for the vegetation there are no detailed studies for this area, except for an abstract on the ecology of the protected area of the Isola Lachea (De Santis \& al., 1995).

The present study is part of a project of research and monitoring activities carried out in the Nature Reserve "Isola Lachea e Faraglioni dei Ciclopi" (nowadays managed by CUTGANA), in order to a correct management of the protected area.

The aim of this research is to provide an updated inventory of the vascular flora and a framework of the plant communities of the Isole dei Ciclopi taking into account their geological setting.

\section{Study area}

The Isole dei Ciclopi are located in the Etnean volcanic district (S.E Sicily), in front of the little village of Acitrezza (Figure 1). Mount Etna Volcano is the largest active volcano in Europe and consists of the products of several overlapping eruptive centers. Rittmann (1973) firstly recognized five different eruptive stages in the etnean volcanic activity. The first stage, named Pre-Etnean stage, corresponds to a long period of submarine and subaerial fissure-type eruptions, whose products are now exposed in the Acitrezza, Acicastello and Ficarazzi area, localized on the lower SE flank of the volcano (Figure 1). Recent classification (Branca \& al., 2011) grouped this products in the Basal Tholeiitic Supersynthem and the literature data are agree to date the eruptive phenomena at about 500000 years ago. 


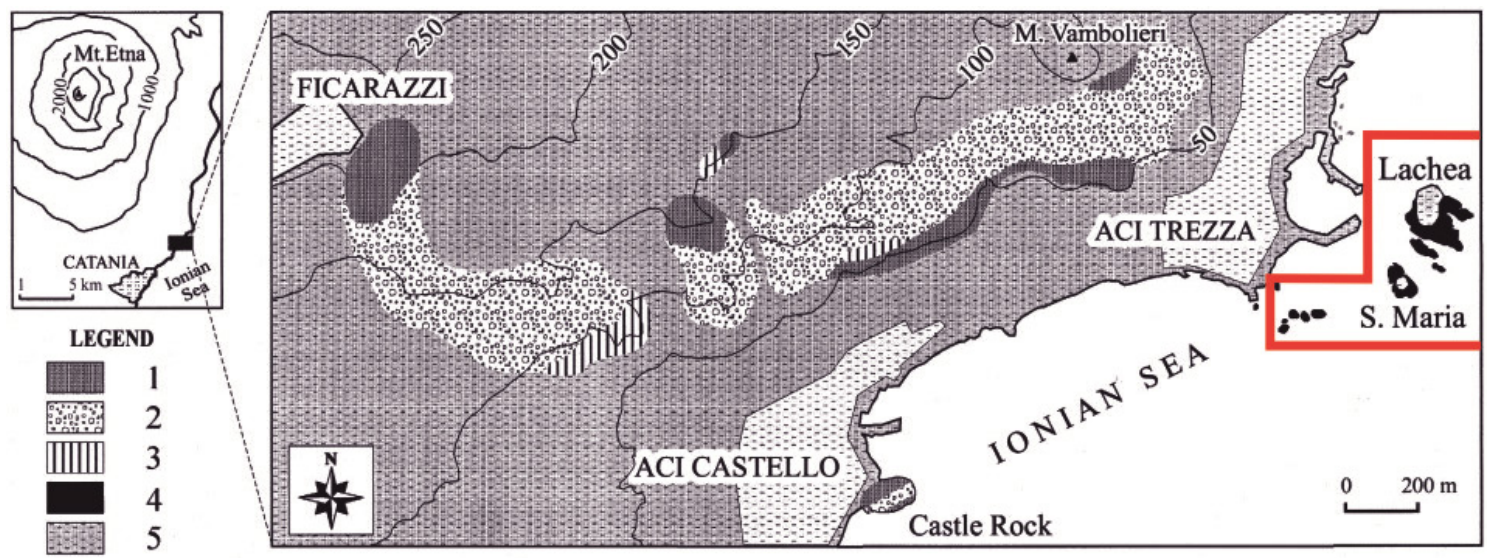

Figure 1. Geological sketch map of the Acicastello-Acitrezza-Ficarazzi area. 1. Pillow-lavas and pillow breccia. 2. Volcaniclastic deposits. 3. Subvolcanic rocks with closely spaced columnar joints. 4. Subvolcanic rocks with widely spaced columnar joints. 5. Younger alkaline volcanics and sedimentary rocks chiefly marly claystones; sands and gravels. Inside the red box are highlighted the Isole dei Ciclopi (after Corsaro \& Cristofolini, 2000; modified).

In the Acitrezza area the volcanic products constitute an archipelago (Isole dei Ciclopi) made by two main islands (Lachea and S. Maria) and six islets. This setting was inherited by the occurrence of a tectonic uplift, causing the subaerial exposition of the volcanic products and associated sediments (see below) and their relative erosion.

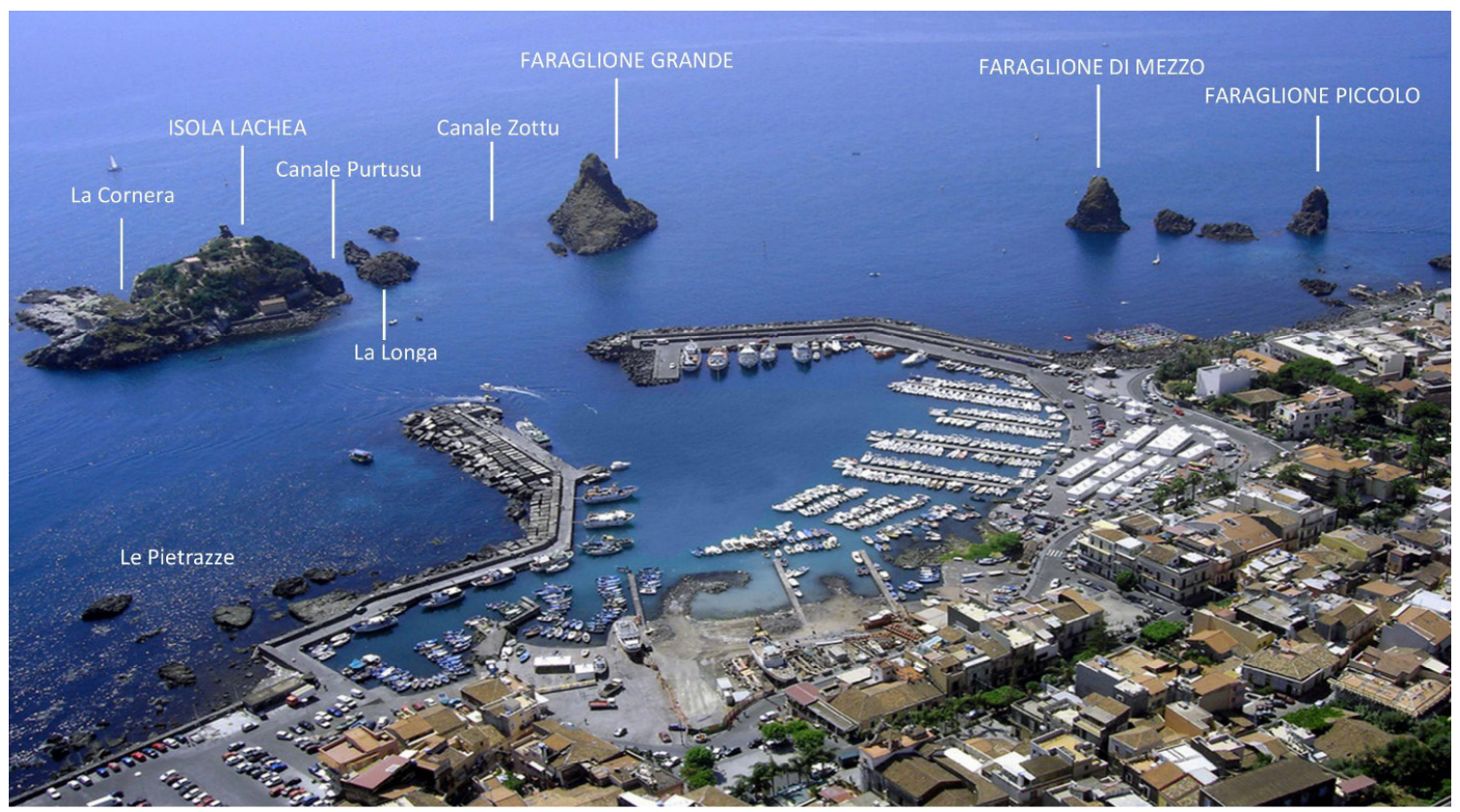

Figure 2. Panoramic view of the study area from west (from CUTGANA).

The Ciclopi Archipelago, covering an area of about 2 ha, can be subdivided in two distinct sectors (Figure 2). The southern one is composed by four islets having a total dimension of few square metres; the biggest are named Faraglione di Mezzo (having 20 meters high and characterized by vertical slopes) and Faraglione Piccolo (high about 10 meters). Every islet is totally made by volcanic products. 
The northern one is located in front of the small harbour of Acitrezza village and includes the Faraglione Grande and the Isola Lachea. The latter represents the biggest island of the Archipelago, having an altitude of about $25 \mathrm{~m}$ above sea level and a surfaces of about 1,5 ha, with a roughly circular shape. Finally the Faraglione Grande is almost conical in shape and reach about 30 meters in high and it is characterized by rather steep surfaces.

The naturalistic high value of the area allowed it to be included in the network of Sites of Community Importance (SCI) according to the Habitats Directive (code ITA070006 Isole dei Ciclopi, cod. ITA070028 Fondali di Acicastello, Isola Lachea - Ciclopi). Furthermore the Archipelago on 1998 was established as a Nature Reserve "Isola Lachea e Faraglioni dei Ciclopi", and on 1989 the arm of the sea between the Archipelago and the Acitrezza harbor began the Marine Protected Area "Isole Ciclopi".

According to a recent phytogeographic subdivision of Sicily (Sciandrello \& al., 2015), this area belongs to the Etna district included in the north-east Sicilian subsector.

According to the bioclimatic classification proposed by Rivas-Martínez (1993, 2004), the investigated territory is referred to the Mediterranean pluviseasonal oceanic bioclimate, with thermotypes low thermomediterranean, and ombrotypes semiarid (or lower humid, Bazan \& al., 2015).

\section{Geological setting of the isole dei ciclopi}

The northern sector of the Ciclopi Archipelago is characterized by the predominant outcrop of basaltic lava rocks (Figure $3 \mathrm{~b}$ ) and marly clays (Figure 3a), withish in color belonging to the "Argille grigio-azzurre" formation (Wezel, 1967). The entire stratigraphic succession is cropping out at the Isola Lachea when the marly clays generally overlie the volcanic products, except on the western sector where the two litotypes are interlayed.

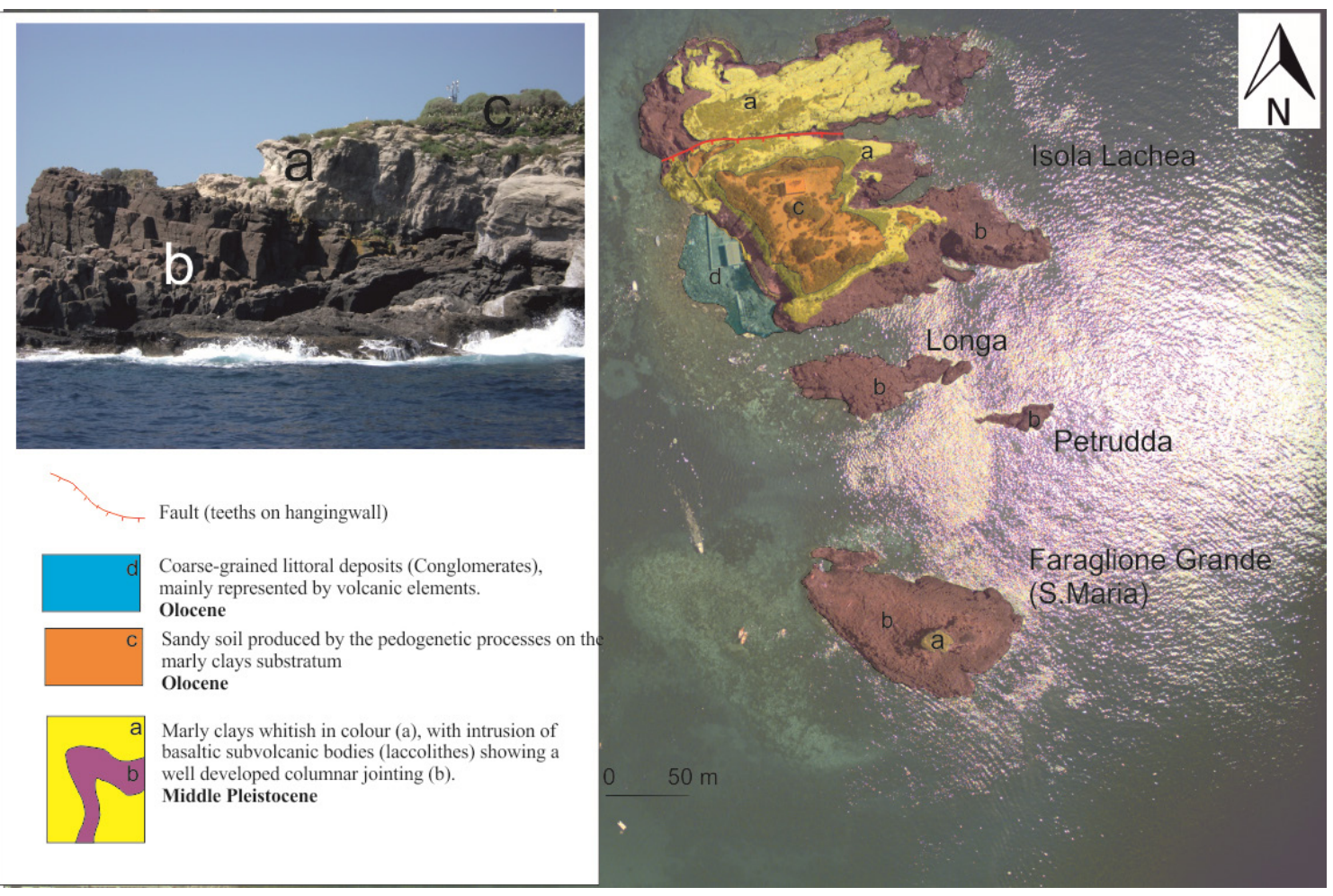

Figure 3. Geological sketch map of the northern sector of the Ciclopi Archipelago. In the picture on the left the overall stratigraphic setting of the Isola Lachea is showed. It is also notable the absence of vegetation characterizing the volcanic surfaces. 
On the top of the Isola Lachea above the marly clays, a thin level of sandy soil is present (Figure 3c). The soil has been mapped only when the thickness exceed $40 \mathrm{~cm}$., and it is typically absent on the volcanic surfaces. Finally, in the east sector of the island a coarse-grained littoral deposit is present (Figure $3 \mathrm{~d})$.

The volcanic rocks outcropping on the area are represented by dolerites-basalts (Analcime basalts, Tanguy, 1978), dark-grey in colour. Volcanic bodies are affected by the "columnar jointing "consisting on decimetric-metric scale fracturing of the rocks due to the occurrence of thermal contraction episodes during the slow transition from the molten to the solid states of the lavas. It is notable, on the lava outcrops, the total absence of scoriaceous surfaces and soils. This feature is probably linked with the eruptive style of the magmatic activity. Indeed, the volcanic activity occurred in the area did not consist on the classical eruptions producing lava flows and pyroclastic products, but in intrusions of magmas inside the soft package of the Pleistocene marly-clays. The intruded magmas chilled in slow way making planar and compact volcanic bodies (laccolites) without scoriaceus horizons whose alteration usually represents the first step of the volcanic soil formation. Furthermore the occurrence of strong winds, due to the exposition of the island, and the steep volcanic surfaces don't allow the accumulation of epiclastic deposits possibly produced by the erosional processes.

The marly clays are represented by finegrained sediments, poorly cemented, except the areas affected by thermal metamorphism close to the volcanic intrusions. This sediments are affected by an intense fracturing centimetric in scale that decreases their hardness. This properties, linked with the occurrences of the outcrops at the top of the island, having a subplanar setting, helps the development and the preservation of the soil above the withish marly clays.

\section{Materials and Methods}

The vegetation analysis was carried out following the phytosociological method (Braun-Blanquet, 1964) taking into account the most recent acquisitions related to symphytosociology and geosymphytosociolo- gy (Biondi, 2011; Rivas Martínez, 2005). A total of 111 phytosociological relevés were performed in the period 2015-2016. Subsequently, data related to halo-nitrophilous scrub vegetation and halophilous plant communities were subjected to multivariate analysis using Syntax 2000 software (Podani, 2001). Original Braun-Blanquet sampling scales were transformed into the ordinal scale according to Van der Maarel (1979). A hierarchic classification method (WPGMA) was performed. Dissimilarity of the relevés was measured using the Euclidean distance coefficient. Syntaxa classification follows Mucina \& al. (2016).

For the correlation between vegetation types and habitats we referred to the Italian Interpretation Manual for the Habitats of Directive 92/43/EEC (Biondi \& al., 2009); while EUNIS coding and status assessment follows Janssen \& al. (2016). The plant communities was mapped using ArcGis 10.3 (ESRI Inc., Redlands, CA, USA).

Plants were collected from all over the study area and also throughout the year to obtain a complete inventory of existing species, noting their local distribution and preferred habitat. The exsiccata (preserved in the Herbarium of University of Catania) were studied with the help of Flora Europaea (Tutin \& al., 1964-80), the Italian floras (Fiori, 1923-29; Pignatti, 1982). Taxonomic nomenclature follows Giardina \& al. (2007). In the list, species and families follow alphabetical order. For each taxon, life form, chorological element, frequency, and local distribution are reported. The life form of each taxon follows the Raunkiaer system as proposed by Pignatti (1982) while the chorological types are adapted from Brullo \& al. (1998).

Moreover, each taxon's frequency in the study area is indicated using the following abbreviations: C (common, spread in several habitats), NC (not common, spread in some habitats), R (rare, localized on specific habitats).

\section{Results and Discussion}

\section{Flora}

The vascular flora of this area consists of 102 specific and infraspecific taxa (Appendix 1). The most represented families are Poaceae 
(18 taxa), Asteraceae (16 taxa) and Fabaceae (7 taxa). The life form spectrum of the vascular flora indicates the predominance of therophytes $(52 \%)$, with hemicryptophytes

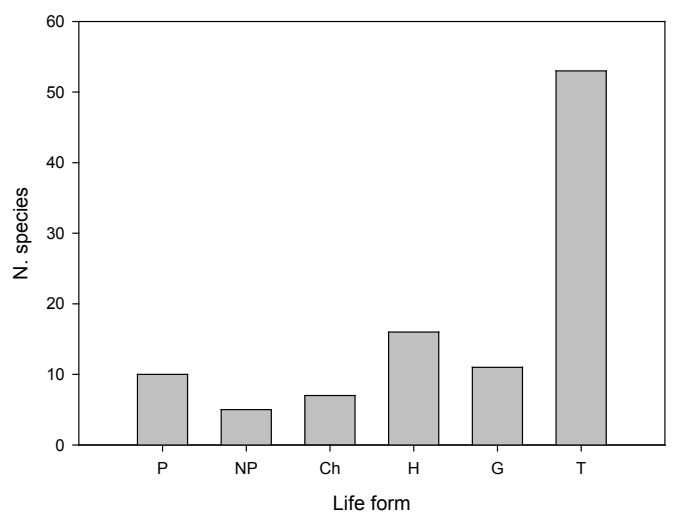

Figure 4. Life form spectrum (102 taxa); P: Phanerophytes; NP: Nanophanerophytes; $\mathrm{Ch}$ : Chamaephytes; H: Hemicryptophytes; G: Geophytes; T: Therophytes.
$(15 \%)$ and phanerophytes (10\%) (Figure 4). From a chorological viewpoint, most species show a Mediterranean distribution (46 taxa) (Figure 5).

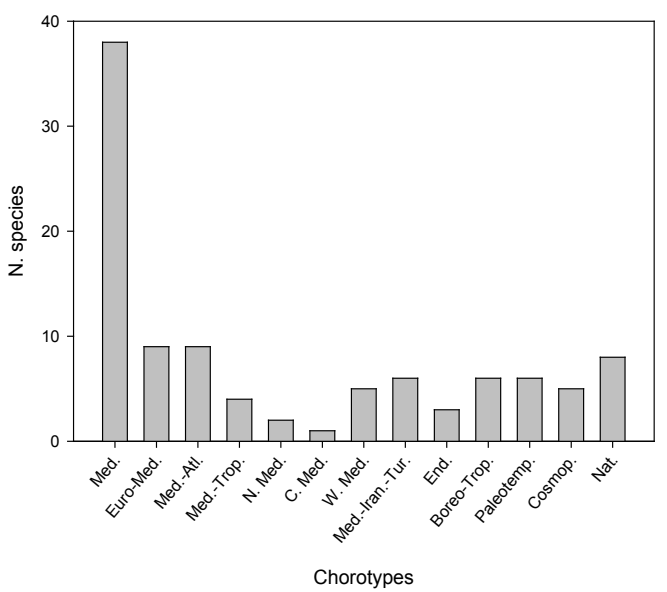

Figure 5. Chorological spectrum. Chorotypes: Med.: Circum-Mediterranean; Euro-Med.:

Euro-Mediterranean; Med.-Atl.: Mediterranean Atlantic; Med.-Trop.: Mediterranean Tropical; N. Med.: North Mediterranean; C. Med.: Centre Mediterranean; W Med.: West Mediterranean; Med.-Iran.-Tur.: Mediterranean-Irano-Turanian; End.: Endemic; Boreo-Trop. Boreo-Tropical; Paleotemp.: Paleotemperate; Cosmop.:

Cosmopolitan; Nat.: Naturalized (chorological types adapted from Brullo \& al., 1998).

scheme (Appendix 2). Cluster analysis of the halophilous (cluster A) and halo-nitrophilous (cluster B) scrubs vegetation allowed to distinguish four main plant communities with specific differential species (Figure 6). The description of each plant community is given below.

\section{Vegetation is described from 111 unpublished relevés collected during the study. A total of 12 plant communities were identified, belonging to 6 classes, as explained in the syntaxonomical \\ Vegetation}




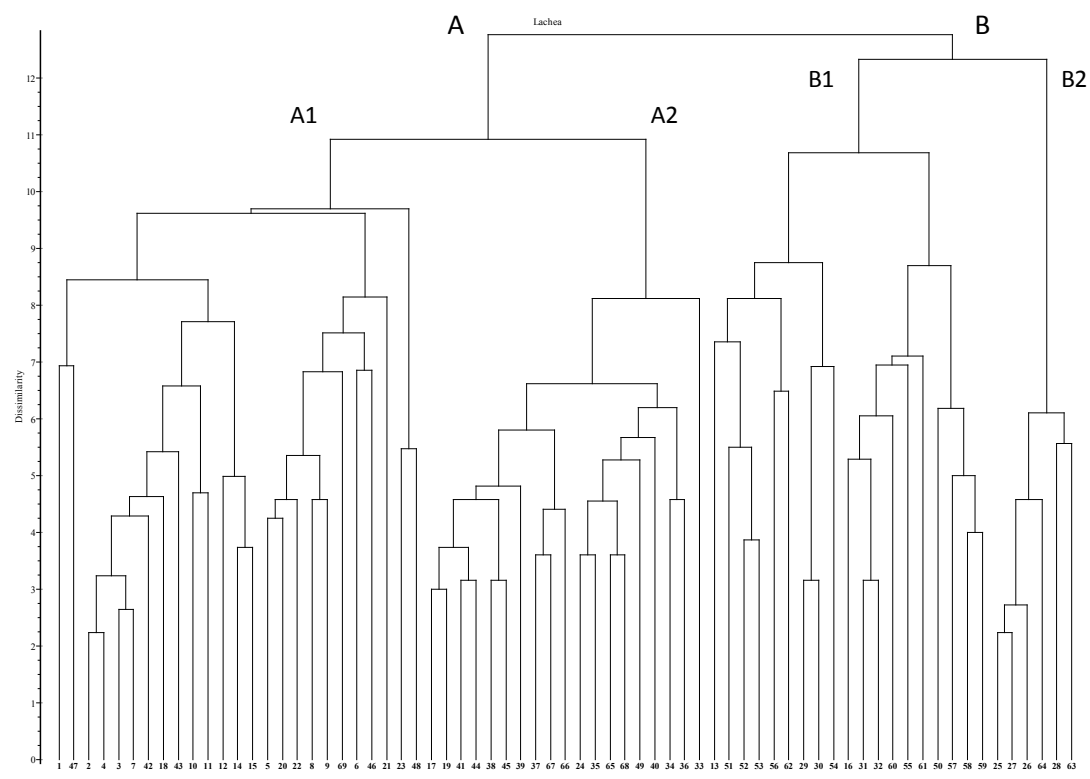

Figure 6. Cluster analysis. Plant communities: A1. Suaedo verae-Atriplicetum halimi, A2. Crithmetum maritimi, B1. Atriplici halimi-Artemisietum arborescentis, B2. Matthiola incana comm.

\section{Rocky coast vegetation}

(Crithmo maritimi-Staticion Molinier 1934)

Crithmetum maritimi Béguinot 1941

(Table 1, cluster A2, Figure 7A)

Characteristic species: Crithmum maritimum

Structure and ecology: Chamaephytic vegetation colonizing the cliffs or gently sloping volcanic outcrops along the sea, influenced by the sea-spray and by the organic waste accumulated during the sea-storms. This association is characterized by the dominance of Crithmum maritimum, mixed with sparse individuals of Lotus cytisoides, Allium commutatum, Capparis orientalis and Matthiola incana. It is linked to thermo-Mediterranean subhumid bioclimatic belt, in catenal contact, towards the inland, with the Pegano-Salsoletea vegetation. In fact as already noted by Biondi (2007) in similar contexts, the rocks closest to the sea, subjected to the actions of the marine aerosol, are colonized by halo-rupicolous pioneer vegetation, while on the less exposed cliffs halotolerant communities grow.

Local distribution: Isola Lachea and Faraglione Grande.

Habitat: EUNIS B3.1b Mediterranean and Black Sea rocky sea cliff and shore (LC); not considered in Habitat Directive.

\section{Rocky cliff vegetation}

(Anthyllidion barbae-jovis Brullo \& De Marco 1989)

Matthiola incana subsp. incana comm.

(Table 1, cluster B2, Figure 7B)

Diagnostic species: Matthiola incana

Structure and ecology: On volcanic rocky cliff, in an almost total absence of soil, grows a sub-halophilous vegetation characterized by dominance of Matthiola incana subsp. incana. According Brullo \& De Marco (1989) this chamaephitic species is characteristic of Anthyllidion barbae-jovis alliance. On the cliff of the Faraglione degli Uccelli the physiognomy of this rupicolous plant communities is given mainly by Matthiola incana subsp. incana and other few species belonging to the Anthyllidion barbae-jovis alliance, as Allium commutatum, Lotus cytisoides and Silene vulgaris subsp.todaroana (Brullo \&De Marco, 1989).

Local distribution: Faraglione di Mezzo

Habitat: EUNIS B3.1b Mediterranean and Black Sea rocky sea cliff and shore (LC); not considered in Habitat Directive.

\section{Perennial halo-nitrophilous vegetation}

(Salsolo vermiculatae-Peganetalia harmalae Br.-B1. \& O.Bolòs 1958) 


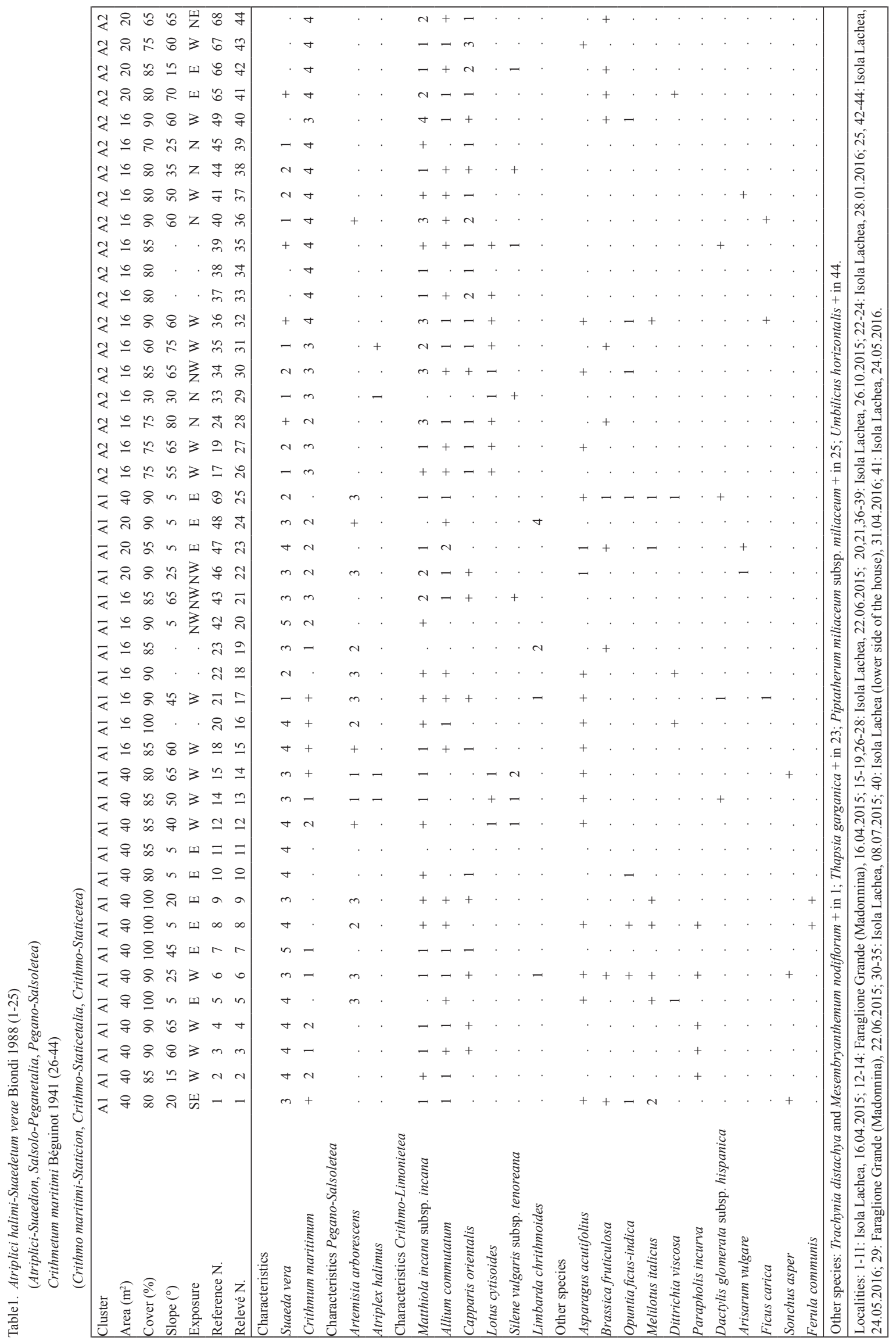




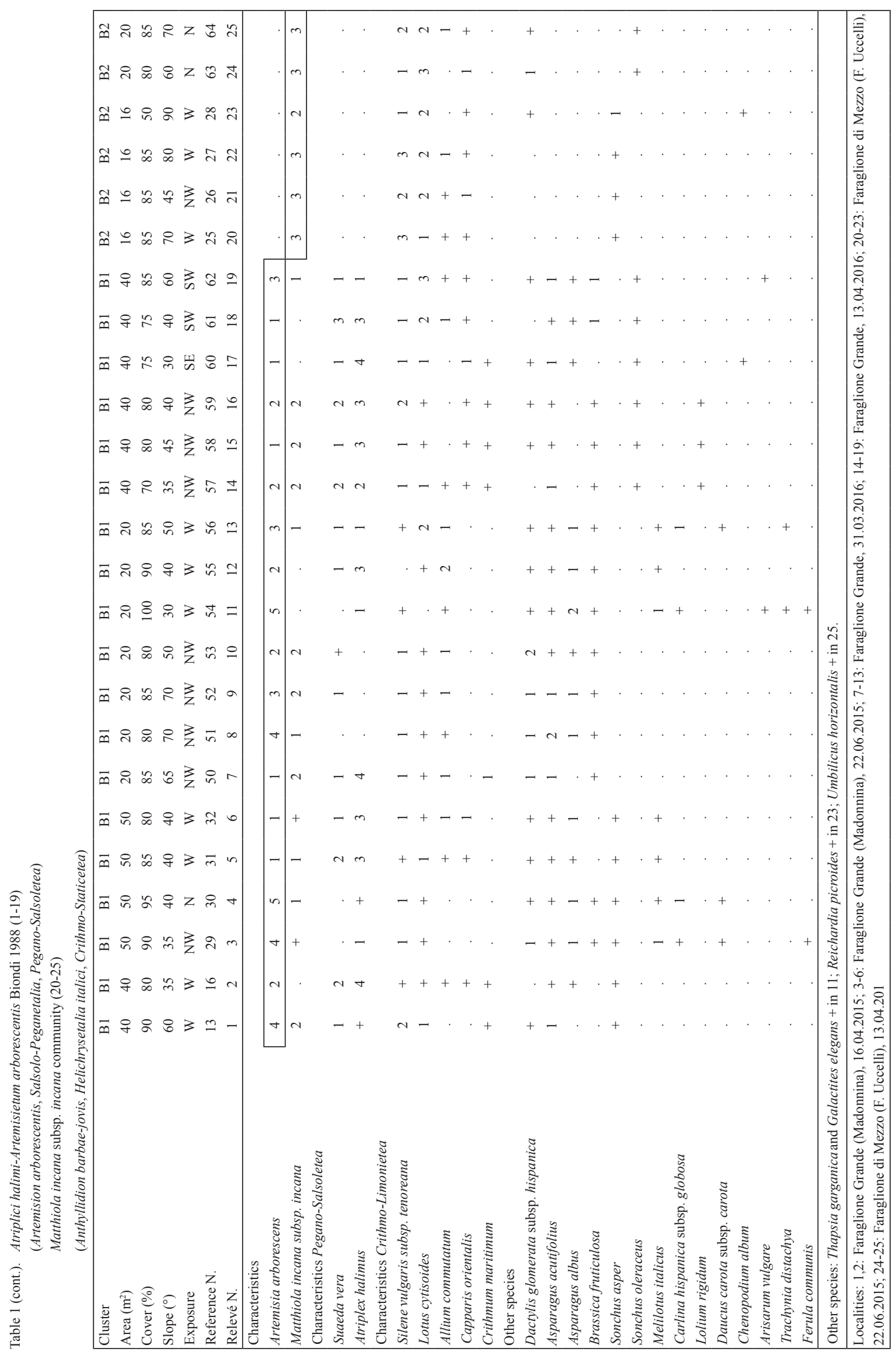



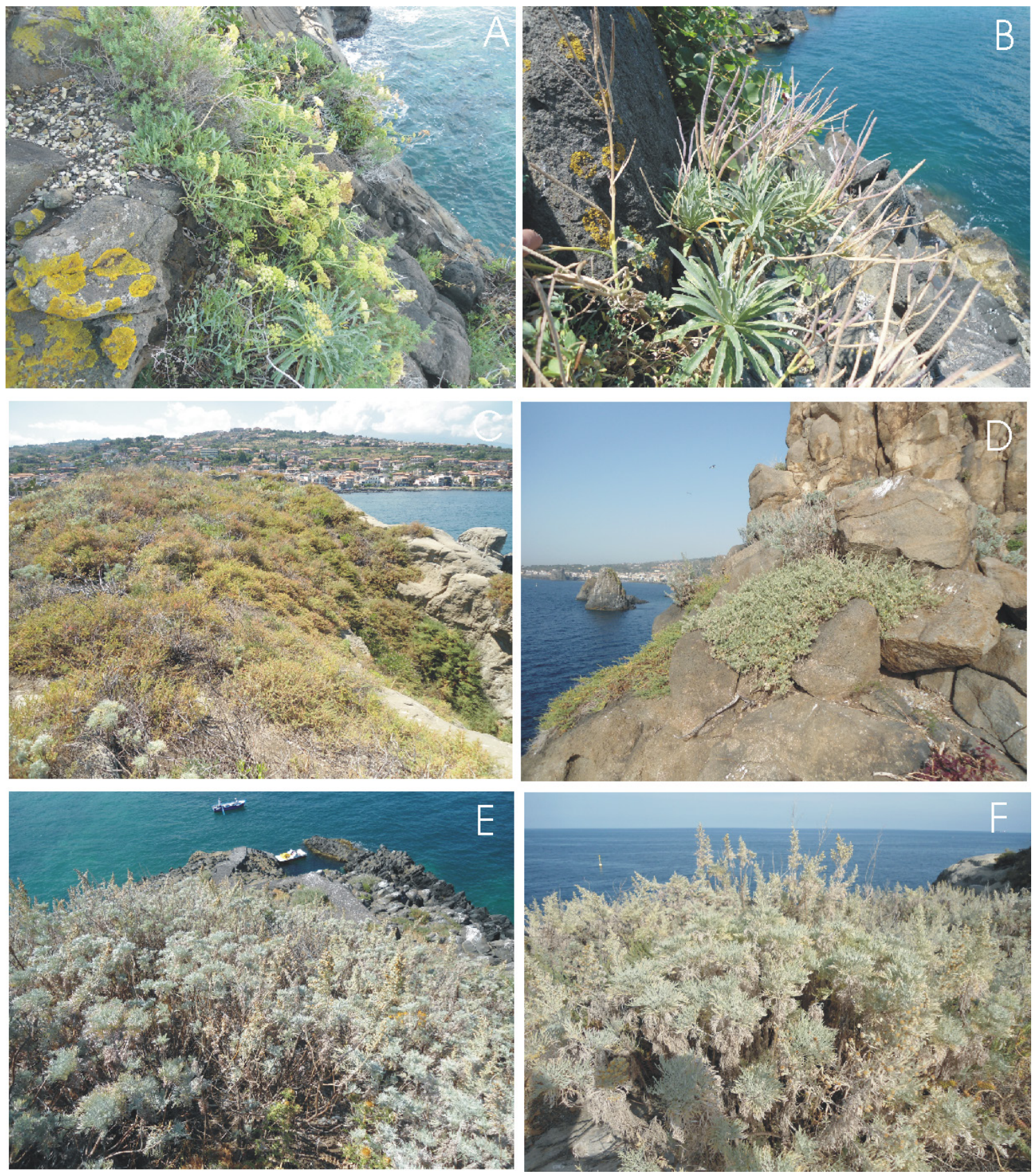

Figure 7. Perennial vegetation. A. Rocky coast vegetation with Crithmum maritimum (Isola Lachea);

B. Rocky cliff vegetation with Matthiola incana (Faraglione di Mezzo); C-D. Halo-nitrophilous vegetation with Suaeda vera e Atriplex halimus (I. Lachea-Faraglione Grande); E-F. Nitrophilous vegetation with Artemisia arborescens (Faraglione Grande and Isola Lachea). The plant communities shown in A-B-D develop on cracks of the basaltic lavas. In $\mathrm{C}$ is visible the substrata represented by marly clays.

Atriplici halimi-Suaedetum verae Biondi 1988 nom. inv. propos.

(Table 1, cluster A1, Figure 7C-D)

Characteristic species: Suaedavera,Atriplex halimus.

Structure and ecology: Halo-nitrophilous plant community colonizing coastal rocky habitats (marls, conglomerates, limestone and sandstone) directly influenced by the seaspray and dunged by the seabirds (Brullo \& al., 2013). The physiognomy is given mainly by Atriplex halimus and the bushes of Suaeda vera, this last species on the Isola Lachea achieving high cover values. In last years, 
the excessive spread of Yellow-legged Gulls (Larus michaellis) on the Islands has favored the reduction of Atriplex halimus and a spread of Suaeda vera, the latter more tolerant nitrophilous species.

Local distribution: Isola Lachea and Faraglione Grande.

Habitat: EUNIS F6.8 Mediterranean halo-nitrophilous scrub (LC); 1430 Halo-nitrophilous scrubs (Pegano-Salsoletea).

\section{Atriplici halimi-Artemisietum arborescentis Biondi 1988}

(Table 1, cluster B1, Figure 7E-F)

Characteristic species: Atriplex halimus, Artemisia arborescens.

Structure and ecology: Synanthropic shrublands dominated mainly by Artemisia arborescens, sometimes growing together with Atriplex halimus and Suaeda vera. This very poor floristic settlement is often found in coastal sites, on marly and conglomeratic substrata, sometimes used as dumping places for urban waste and rubbles (Biondi \& al., 1988). It can be considered as a permanent edaphic community whose evolution is contrasted by the human disturbance, combined to the action of coastal winds, seabirds, salt-spray (Brullo \& al., 2013). It is found within the thermo-Mediterranean dry to subhumid bioclimatic belt, often in contact with the Oleo-Ceratonion vegetation.

Local distribution: Isola Lachea and Faraglione Grande.

Habitat: EUNIS F6.8 Mediterranean halo-nitrophilous scrub (LC); 1430 Halo-nitrophilous scrubs (Pegano-Salsoletea).

\section{Halo-nitrophilous and sub-halophilous an- nual vegetation}

(Frankenion pulverulentae Rivas-Martínez ex Castroviejo \& Porta 1976)

Trifolio scabri-Catapodietum balearici Brullo et Giusto del Galdo 2003

(Table 2, rels. 1-13)

Characteristic species: Trifolium scabrum, Catapodium balearicum.

Structure and ecology: Halo-nitrophilous association colonizing the rocky coastal. This annual vegetation grows on in particular areas on flat surfaces with a few centimeters of soil, subject to marine-spray within the Thermo-mesomediterranean bioclimatic belt (Rivas Martínez $\& a l ., 2004)$. It is in catenal contact with the halo-nitrophilous plant communities of the Atriplici halimi-Suaedetum verae. The structure of Trifolio scabri-Catapodietum balearici is given mainly by Catapodium balearicum and several species belonging to the Saginetea maritimae class (Brullo \& Giusso, 2003), as Spergularia bocconi, Plantago coronopus, Parapholis incurva, Sagina maritima, Trifolium scabrum, Mesembryanthemum nodiflorum, Polycarpon tetraphyllum subsp. diphyllum etc. The surfaces rich in nitrates, with little deeper soils and not very sunny, the Trifolio scabriCatapodietum balearici is replaced by a vegetation dominated by Mesembryanthemum nodiflorum (Figure 8C).

Local distribution: Isola Lachea.

Habitat: EUNIS A2.6513 - Salicornia spp. pioneer saltmarshes; 1310 Salicornia and other annuals colonizing mud and sand.

\section{Parapholido incurvae-Spergularietum bocconei} Brullo, Scelsi \& Spampinato 2001

(Table 2, rels. 14-23, Figure 8A-B)

Characteristic species: Spergularia bocconei, Parapholis incurva.

Structure and ecology: This vegetation prefers more or less the same ecological conditions of Trifolio scabri-Catapodietum baleari$c i$ with some differences linked to an increased need to nitrates and very shallow soils. It is in catenal contact with the halo-nitrophilous plant communities of the Crithmo maritimiStaticetea. The structure is given mainly by Spergularia bocconi and Parapholis incurva and other few species belonging to the Saginetea maritimae class (Brullo \& Giusso, 2003), as Spergularia salina, Parapholis incurva and Sagina maritima.

Local distribution: Isola Lachea and Faraglione Grande.

Habitat: EUNIS A2.6513 - Salicornia spp. pioneer saltmarshes; 1310 Salicornia and other annuals colonizing mud and sand.

\section{Scrub vegetation}

(Oleo sylvestris-Ceratonion siliquae Br.-B1. ex Guinochet \& Drouineau 1944 em. Rivas-Martinez 1975)

Asparago acutifolii-Oleetum sylvestris Bacchetta et al. 2003

(Table 3, rels. 1-7)

Diagnostic species: Olea europaea var. sylvestris. 


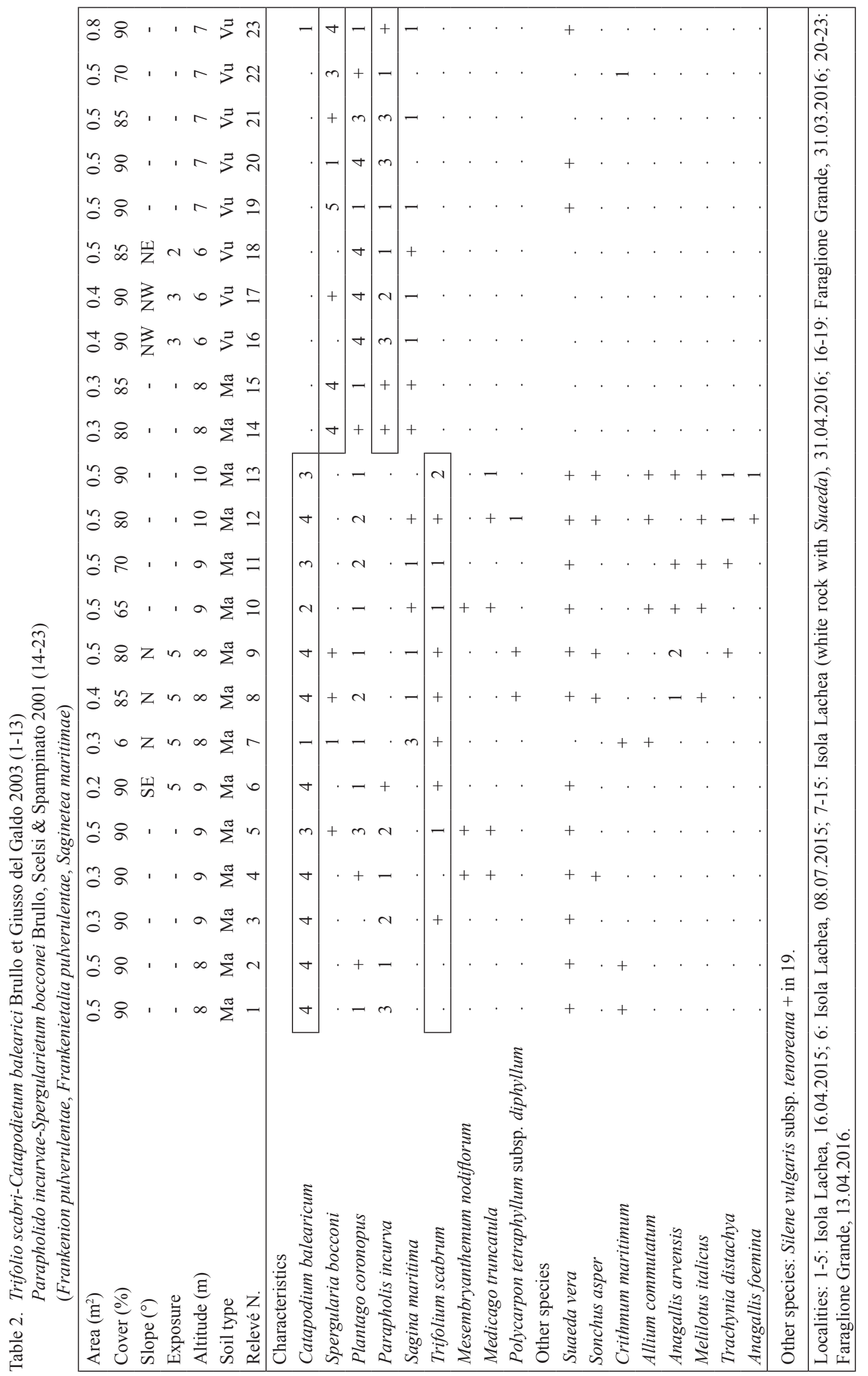


Table 3. Rubus ulmifolius community

(Pruno spinosae-Rubion ulmifolii, Pyro spinosae-Rubetalia ulmifolii, Crataego-Prunetea)

\begin{tabular}{|c|c|c|c|c|c|c|c|c|c|c|c|c|c|}
\hline Altitude (m) & 25 & 25 & 25 & 25 & 25 & 25 & 26 & 24 & 24 & 24 & 23 & 24 & 24 \\
\hline Area $\left(\mathrm{m}^{2}\right)$ & 20 & 20 & 20 & 20 & 20 & 20 & 20 & 20 & 20 & 20 & 20 & 20 & 20 \\
\hline Cover (\%) & 90 & 90 & 90 & 90 & 90 & 100 & 100 & 95 & 95 & 95 & 100 & 90 & 100 \\
\hline Slope $\left(^{\circ}\right)$ & 45 & 35 & 55 & 45 & 40 & - & 5 & 30 & 30 & 30 & - & 35 & 40 \\
\hline Exposure & $\mathrm{W}$ & $\mathrm{W}$ & W & $\mathrm{W}$ & W & - & $\mathrm{E}$ & $\mathrm{N}$ & $\mathrm{N}$ & $\mathrm{N}$ & - & $\mathrm{N}$ & $\mathrm{W}$ \\
\hline Soil & $\mathrm{Ma}$ & $\mathrm{Ma}$ & $\mathrm{Ma}$ & $\mathrm{Ma}$ & $\mathrm{Ma}$ & $\mathrm{Ma}$ & $\mathrm{Ma}$ & $\mathrm{Ma}$ & $\mathrm{Ma}$ & $\mathrm{Ma}$ & $\mathrm{Ma}$ & $\mathrm{Ma}$ & $\mathrm{Ma}$ \\
\hline Relev. No. & 1 & 2 & 3 & 4 & 5 & 6 & 7 & 8 & 9 & 10 & 11 & 12 & 13 \\
\hline \multicolumn{14}{|l|}{ Characteristics } \\
\hline Asparagus acutifolius & 1 & 1 & + & 1 & + & 2 & + & + & + & . & 1 & 1 & . \\
\hline Rubus ulmifolius & 2 & 1 & 2 & 1 & 1 & + & . & 4 & 2 & 4 & 3 & 1 & 4 \\
\hline \multicolumn{14}{|l|}{ Characteristics Oleo-Ceratonion } \\
\hline Olea europaea var. sylvestris & 4 & 3 & 4 & 4 & 3 & 4 & 5 & . & 1 & . & 1 & + & . \\
\hline Arisarum vulgare & 1 & 1 & 1 & 1 & 1 & 1 & 4 & . & . & . & . & . & . \\
\hline \multicolumn{14}{|l|}{ Other species } \\
\hline Opuntia ficus-indica & 3 & 2 & 3 & 2 & 4 & 1 & 1 & 1 & 2 & 2 & 2 & + & . \\
\hline Ailanthus altissima & 2 & 1 & 2 & 3 & 1 & . & . & 4 & 3 & 3 & 2 & . & . \\
\hline Brassica fruticulosa & 1 & 2 & 1 & 2 & 1 & + & . & 2 & 1 & 1 & 1 & + & . \\
\hline Spartium junceum & 2 & 1 & 3 & 1 & 2 & . & . & 2 & 1 & . & 2 & 4 & 1 \\
\hline Matthiola incana subsp. incana & 2 & 1 & 1 & 1 & 1 & + & + & . & + & + & + & + & + \\
\hline Capparis orientalis & 1 & + & + & + & + & + & + & + & + & . & + & + & . \\
\hline Dittrichia viscosa & . & + & . & + & + & . & . & + & + & + & + & + & . \\
\hline Dactylis glomerata subsp. hispanica & + & + & . & + & + & . & . & . & + & + & + & + & . \\
\hline Acanthus mollis & + & + & + & + & + & + & + & . & . & + & . & . & . \\
\hline Thapsia garganica & + & + & + & 1 & . & . & . & + & + & . & + & + & . \\
\hline Mercurialis annua & + & + & + & + & + & + & + & + & + & + & + & + & . \\
\hline Piptatherum miliaceum subsp. miliaceum & . & . & . & + & . & . & . & + & + & . & + & + & . \\
\hline Ficus carica & 1 & 1 & + & . & . & . & . & 1 & . & . & 1 & + & 2 \\
\hline Carlina hispanica subsp. globosa & . & . & . & + & . & . & . & . & + & . & . & 1 & . \\
\hline Galactites elegans & . & . & . & . & + & . & . & + & . & . & . & + & . \\
\hline Allium commutatum & . & . & . & . & . & . & . & . & . & . & . & + & + \\
\hline Daucus carota subsp. carota & . & . & . & . & . & . & . & . & . & . & + & + & . \\
\hline Arundo donax & . & . & . & . & . & . & . & 2 & 1 & . & . & . & . \\
\hline
\end{tabular}

Structure and ecology: On top of Lachea island and Faraglione Grande grows a evergreen vegetation dominated by Olea europaea var. sylvestris. Small plant species of the Oleo-Ceratonion alliance are presence, such as Arisarum vulgare, Prasium majus and Asparagus acutifolius. For its ecological characteristics this plant community can be referred to Asparago acutifolii-Oleetum sylvestris, association described by Bacchetta (2003) for Sardinia. In some parts of the island Lachea the Olea europaea communities are mixed with Spartium junceum, Opuntia ficus-indica, Ailanthus altissima, in particular the latter two species often tend to alter the typical structure of the shrub community and especially to steal the habitat of indigenous communities.

Local distribution: Isola Lachea and Faraglione Grande.

Habitat: F5.51 Thermo-Mediterranean brushes, thickets and heath-garrigues (VU); 9320 Foreste di Olea e Ceratonia. 

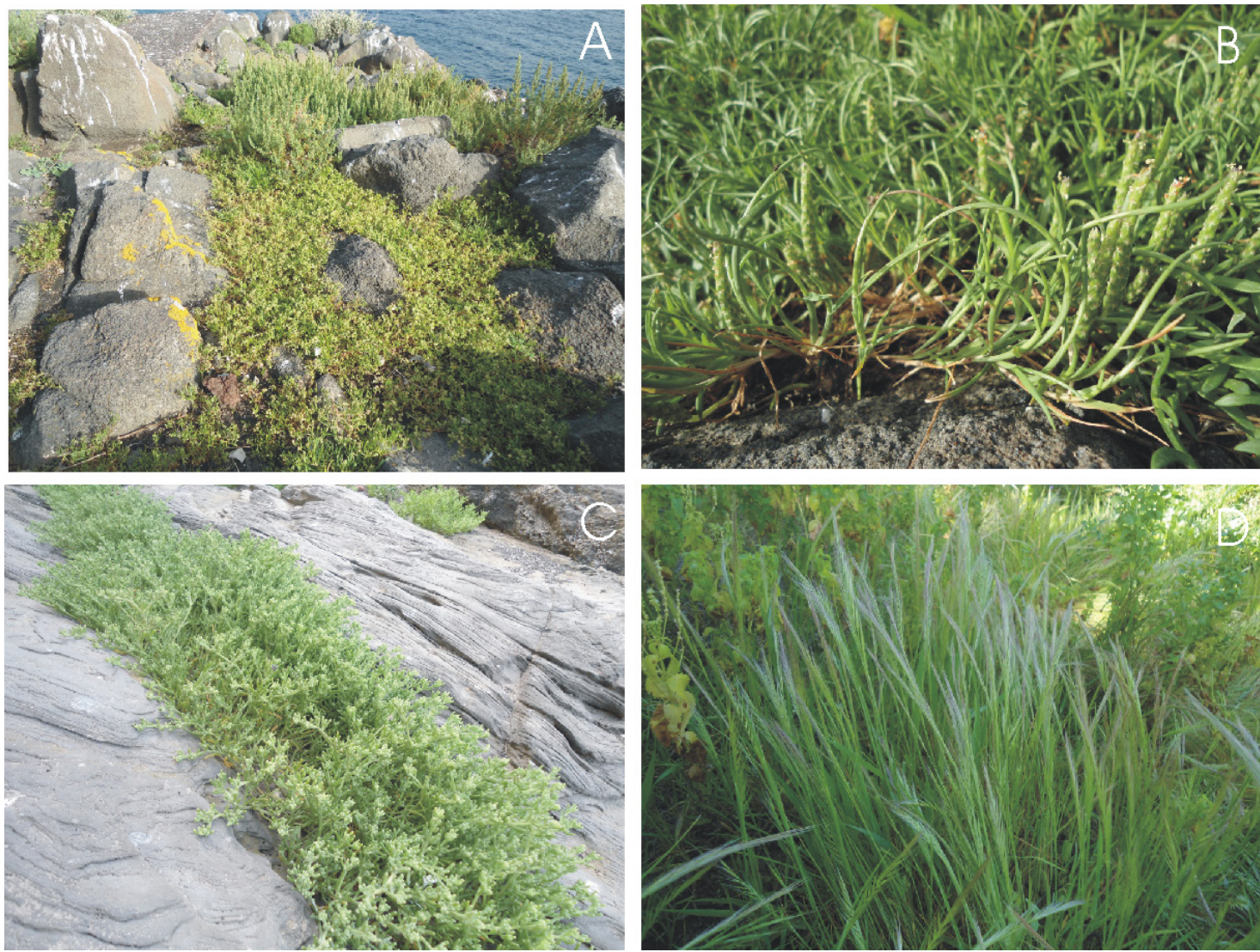

Figure 8. Annual vegetation. A-B. Sub-halophilous vegetation with Spergularia bocconei and Parapholis incurva (Faraglione Grande); C. Halo-nitrophilous vegetationwith Mesembryanthemum nodiflorum (Isola Lachea); D. Nitrophilous vegetation with Vulpia geniculata (Isola Lachea).

\section{Synanthropic vegetation}

(Pruno-Rubion ulmifolii O. Bolòs 1954, AlliontriquetriO.Bolòs 1967, EchioplantagineiGalactition tomentosae O. Bolòs \& Molinier 1969)

\section{Rubus ulmifolius comm.}

(Table 3, rels. 8-13)

Diagnostic species: Rubus ulmifolius.

Structure and ecology: As a result of the degradation of maquis, a secondary shrub develops on moist, nitrate rich soils. This vegetation occupying in particular the north-facing slopes, in proximity of geological fractures of the Isola Lachea. From a structural viewpoint, this vegetation is characterized by intricate, almost impenetrable bushes, such as Rubus ulmifolius, Ficus carica and Spartium junceum. Moreover, this community hold several synanthropicandalienspecies, as Opuntiaficus-indica, Ailanthus altissima, Arundo donax, Robinia pseudoacacia, Brassica fruticulosa, Dittrichia viscosa, Mercurialis annua, Piptatherum miliaceum subsp. miliaceum, Daucus carota, etc.

Local distribution: Isola Lachea.

Habitat: EUNIS F3.23 Tyrrhenian sub-mediterranean deciduous thickets; not considered in Habitat Directive.

\section{Acanthus mollis comm.}

(Table 4, rels. 1-3)

Diagnostic species: Acanthus mollis

Structure and ecology: Anthropogenic vegetation of sciaphilous and nitrophilous, perennial or annual herbs that grows on deep and nutrient-rich soils (Biondi \& al., 2014). This plant community, with a winter-spring cycle, is localized in the shade of olive trees (Olea europaea var. sylvestris) of the Lachea Island. It is prefer ruderal environments with deep soils, rich in organic matter. The physiognomy of this community is given by the dominance of Acanthus mollis normally achieving 
Table 4. Galactites elegans community

(Echio-Galactition tomentosae, Brometalia rubenti-tectorum, Chenopodietea)

\begin{tabular}{|c|c|c|c|c|c|c|c|c|c|}
\hline Area $\left(\mathrm{m}^{2}\right)$ & 20 & 20 & 20 & 20 & 40 & 20 & 20 & 10 & 10 \\
\hline Cover $(\%)$ & 90 & 95 & 100 & 100 & 100 & 100 & 90 & 90 & 90 \\
\hline Slope $\left(^{\circ}\right)$ & - & - & - & - & - & 5 & 5 & 5 & 5 \\
\hline Exposure & - & - & - & - & - & $\mathrm{N}$ & NW & $\mathrm{W}$ & $\mathrm{W}$ \\
\hline Altitude (m) & 10 & 10 & 10 & 10 & 10 & 11 & 8 & 10 & 10 \\
\hline Relev. No. & 1 & 2 & 3 & 4 & 5 & 6 & 7 & 8 & 9 \\
\hline \multicolumn{10}{|l|}{ Characteristics } \\
\hline Acanthus mollis & 4 & 3 & 3 & 1 & 1 & 1 & . & + & + \\
\hline Galactites elegans & 1 & + & 2 & 4 & 4 & 4 & 3 & 1 & 1 \\
\hline \multicolumn{10}{|l|}{ Characteristics Epilobietea \& Allion triquetri } \\
\hline Arisarum vulgare & 2 & 3 & 1 & 1 & 1 & . & + & . & + \\
\hline Urtica membranacea & + & 1 & + & . & + & 1 & . & . & . \\
\hline Parietaria lusitanica & + & + & + & . & . & 1 & . & . & . \\
\hline Galium aparine subsp. aparine & + & . & + & . & . & + & . & . & . \\
\hline \multicolumn{10}{|l|}{ Characteristics Papaveretea \& Brometalia } \\
\hline Mercurialis anпua & 1 & 2 & 1 & 3 & 1 & 2 & . & + & 2 \\
\hline Erodium malacoides & . & . & + & + & + & + & . & + & 1 \\
\hline Brassica fruticulosa & + & . & + & 1 & 1 & 1 & 2 & + & . \\
\hline Sonchus oleraceus & . & . & . & . & . & 1 & 1 & + & + \\
\hline Anisantha madritensis & . & . & . & . & . & + & . & 3 & 2 \\
\hline Glebionis coronaria & . & . & . & . & . & 3 & . & 1 & 1 \\
\hline Solanum nigrum & . & . & + & + & . & . & . & . & . \\
\hline Vulpia geniculata & . & . & . & . & . & . & . & 3 & 3 \\
\hline Melilotus italicus & . & . & . & . & . & . & . & + & + \\
\hline Catapodium rigidum & . & . & . & . & . & . & . & + & + \\
\hline Anagallis arvensis & . & . & . & . & . & . & . & 1 & + \\
\hline Vulpia ciliata & . & . & . & . & . & . & . & 2 & 1 \\
\hline \multicolumn{10}{|l|}{ Other species } \\
\hline Thapsia garganica & + & + & . & + & . & + & 1 & + & + \\
\hline Asparagus acutifolius & + & + & + & + & + & . & + & . & . \\
\hline Carlina hispanica subsp. globosa & . & + & . & + & + & + & . & 1 & . \\
\hline Ferula communis & + & . & + & 1 & 1 & 1 & . & . & . \\
\hline Trachynia distachya & . & . & . & . & . & + & 1 & 1 & 1 \\
\hline Allium commutatum & + & . & . & + & . & . & 1 & . & . \\
\hline Dittrichia viscosa & . & . & 1 & . & 1 & 2 & . & . & . \\
\hline Valantia muralis & . & . & . & . & . & . & . & + & + \\
\hline Polycarpon tetraphyllum subsp. diphyllum & . & . & . & . & . & . & . & + & 1 \\
\hline Cerastium pumilum & . & . & . & . & . & . & . & + & + \\
\hline Ailanthus altissima & . & . & . & + & + & . & . & . & . \\
\hline \multicolumn{10}{|c|}{$\begin{array}{l}\text { Characteristics Papaveretea \& Brometalia: Hordeum murinum subsp. leporinum, Lolium rigidum, Plantago lagopus } \\
\text { and Sonchus asper } 2 \text { in 7; Urospermum picroides }+ \text { in } 8 . \text { Other species: Erigeron bonariensis }+ \text { in } 6 ; \text { Dactylis } \\
\text { glomerata subsp. hispanica 2, Silene vulgaris subsp. tenoreana 1, Trifolium scabrum, Sedum rubens and Asparagus } \\
\text { albus }+ \text { in } 7 .\end{array}$} \\
\hline \multicolumn{10}{|c|}{$\begin{array}{l}\text { Localities: 1-5: Isola Lachea, 28.01.2016; 6: Isola Lachea, 31.04.2016; 7: Faraglione Grande (under Madonnina), } \\
\text { 31.04.2016; 8-9: Isola Lachea, 31.04.2016. }\end{array}$} \\
\hline
\end{tabular}


high cover values, mixed with several other nitrophilous species, as Urtica membranacea, Parietaria lusitanica, Galium aparine subsp. aparine, Mercurialis annua, Galactites elegans, Erodium malacoides, ect.. In Sicily, this vegetation is widespread in the thermo-mesomediterranean bioclimatic belt (Brullo \& Marcenò, 1985)

Local distribution: Isola Lachea.

Habitat: not considered in EUNIS and Habitat Directive.

\section{Galactites elegans comm.}

(Table 4, rels. 4-9)

Diagnostic species: Vulpia geniculata and Galactites elegans.

Structure and ecology: Annual, subnitrophilous, thermoxerophilous, herbaceous communities that grow in abandoned and fallow fields, along roadsides and in disturbed areas in the Mediterranean region (Biondi \& al., 2014). On the Lachea Island is widespread an annual weeds, a consequence of abandoning crops that have affected the island in the past. This vegetation is characterized by a rich contingent of nitrophilous species, including Anisantha madritensis, Anagallis arvensis, Brassica fruticulosa, Catapodium rigidum, Cerastium pumilum, Dittrichia viscosa, Erodium malacoides, Glebionis coronaria, Galactites elegans, Hordeum leporinum, Lolium rigidum, Melilotus italicus, Mercuriales annua, Plantago lagopus, Polycarpon dyphyllum, Sonchus oleraceus, Trachynia distachya, Trifolium scabrum, Urospermum picroides, Valantia muralis, Vulpia geniculata, V. ciliata, etc. mixed with some perennial species of Lygeo-Stipetea, as Carlina corymbosa, Ferula communis, Dactylis hispanica and Thapsia garganica. On the whole this community is referred to Echio plantaginei-Galactition tomentosae, alliance which groups the subnitrophilous vegetation of abandoned fields. In some well-sunny areas in less nitrophilous conditions, of the island Lachea, Vulpia geniculata assumes a significant structural role (Figure 8), forming mono- phitic community in contact with evergreen shrubs of Olea europaea.

Local distribution: Isola Lachea and Faraglione Grande.

Habitat: EUNIS E1.6 Mediterranean subnitrophilous grass communities; not considered in Habitat Directive.

\section{Vegetation map}

The processing of the vegetation map allowed to define 9 different vegetation types (Figure $9)$. For each one the phytosociological sintaxon (association or higher-order syntaxa), habitats and coverage in square meters (sqm) is indicated. The different types have been adapted to better respond to the mapping scale (1: 1.000). Some vegetation types, occupying very limited areas (as Saginetea maritimae communities), have not been mapped.

On the investigated territory, a total of about 2.5 ha, the $62 \%$ is characterized by the presence of the basaltic rocks without vegetation $\left(15668 \mathrm{~m}^{2}\right)$.

The plant communities, most represented on the Island, are the halo-nitrophilous vegetation of Pegano-Salsoletea with an area of about $4,458 \mathrm{~m}^{2}(18 \%)$, within which micro-communities of Saginetea maritimae are growing, but not mappable due to the small cover of this vegetation. These associations cover mainly the marly-clays outcrops.

Poorly represented are the evergreen shrub communities dominated by Olea europaea $\left(900 \mathrm{~m}^{2}, 4 \%\right)$, as well as the salt-tolerant plant communities of the rocky coast with Crithmum maritimum $\left(955 \mathrm{~m}^{2}, 4 \%\right)$ and uncultivated vegetation of the Echio-Galactition $\left(632 \mathrm{~m}^{2}, 2 \%\right)$ and the bushes of Rubus ulmifolius $\left(219 \mathrm{~m}^{2}\right.$, $1 \%$ ). Moreover a strong threat is represented by alien species that occupy considerable surfaces, especially Opuntia ficusindica $\left(1534 \mathrm{~m}^{2}, 6 \%\right)$ and Ailanthus altissima $\left(590 \mathrm{~m}^{2}, 2 \%\right)$. All these associations are widespread on the top of the island, where the soil is present. 


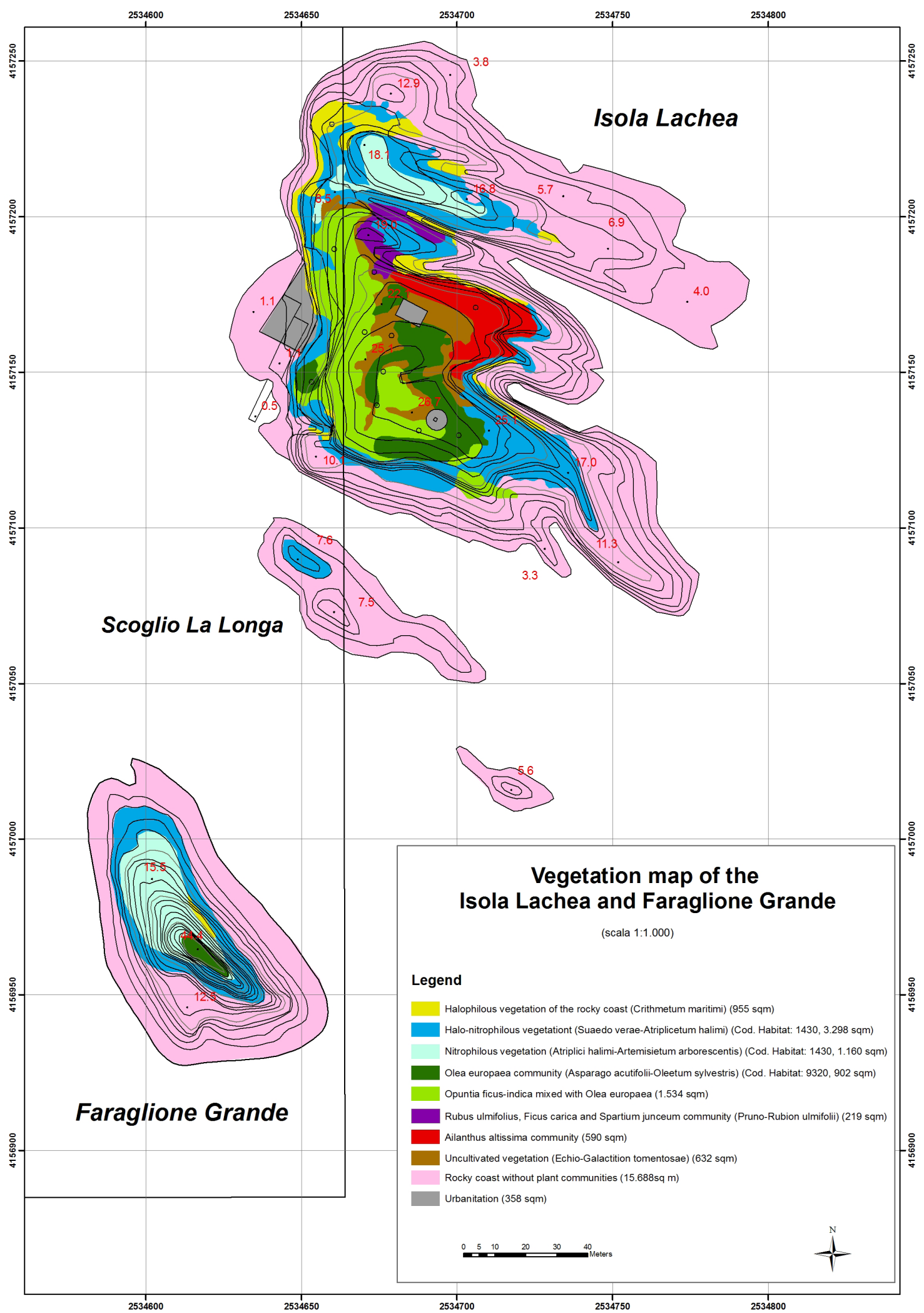

Figure 9. Vegetation map of the northern sector of the Ciclopi Archipelago 


\section{Conclusion}

The results of the current flora (102 entities) of the Isole Ciclopi show a moderate floristic richness taking into account the small size of the islets. Previously Siracusa (1995) reports a total of 180 species, considering also those cited by other authors (Nicotra, 1893; Zodda, 1911; Musmarra, 1941), but by the same author only 91 taxa were counted in 1995 .

The flora richness in the last 100 years has clearly suffered a sharp drop, especially on the Lachea island. Musmarra (1941) signaled some pteridophytes now totally absent, as Adiantum capillus-veneris L., Asplenium obovatum Viv., Asplenium trichomanes L., Ceterach officinarum Willd., Polypodium cambricum L., Dryopteris pallida (Bory) C. Chr. ex Maire \& Petitm., probably due to a lower edaphic humidity compared to that of the past.

Furthermore some of the species reported recently from Siracusa (1995) were not found, as Euphorbia dendroides, Halimione portulacoides, Heliotropium bocconei, Reichardia picroides var. maritima, Senecio cineraria subsp. bicolor. Probably the disappearance of these species is linked to the spread of some invasive alien species (Ailanthus altissima, Opuntia ficus-indica, Arundo donax) that in some cases cover large areas (Figure 10), replacing the natural habitats and characteristic species. The invasion of alien species in Isole Ciclopi is a further confirmation of a widespread phenomenon in the coastal areas of Sicily (Sciandrello \& al., 2013, 2014, 2016) and surrounding islets (Minissale \& al., 2005; Pretto \& al., 2012; Minissale \& Sciandrello 2017). Another important cause of the disappearance of some plant species or natural habitat is the excessive spread of Yellow-legged Gulls (Larus michahellis) in the spring and summer colonize the entire island for nesting, thus affecting the delicate ecological balance between plants, animals and soil, for the supply, with their droppings, of significant quantities of nitrates as already noted by Gristina \& Marcenò (2008) for a coastal area of north-west Sicily.

In addition there are various exotic introduced as ornamental species such as Casuarina equisetifolia, Thuja orientalis, Pittosporum tobira, Robinia pseudoacacia, which have greatly changed the physiognomy of the Isola Lachea plant landscape's, especially on the summit plateau.
So overall, the various forms of disturbance on habitats and flora over time have resulted in a significant depletion of the floristic and phytocenotic diversity of the islets.

On the other hand, despite these disturbances a good correlation between the plant communities distribution and the stratigraphic succession is still clearly recognizable and appears of a sure interest. In particular the basal areas of the islands, characterized by presence of basalts, are dominated by halophilous communities of Crithmo-Limonietea present mostly on the cracks affecting the volcanic bodies (columnar joint) that are sometimes filled by thin thikness of soil. In the medium slopes, characterized by marly-clays exposures, we find mainly a nitrophilous and halo-nitrophilous vegetation of Pegano-Salsoletea that prefers a soft substrata (here represented by the marly clays) having a thin layer of soil. Finally on the top of the island, characterized by the presence of sandy soil exceeding $40 \mathrm{~cm}$ in thickness, grows evergreen vegetation of the Oleo-Ceratonion alliance.

The vegetation results helped define objectively habitats, according to Directive 43/92/ EEC, which are present on the Isole Ciclopi. In particular, except for the habitat of marine type Reefs 1170 here not investigated, on the islands were surveyed the following habitats: 1310 Salicornia and other annuals colonizing mud and sand, 1430 Halo-nitrophilous scrubs (Pegano-Salsoletea), 9320 Foreste di Olea e Ceratonia. In addition the habitat 5330 Thermo-Mediterranean and pre-desert scrub and 6220 * Pseudo-steppe with grasses and annuals of the Thero-Brachypodietea shown in the Standard Data Form, are excluded for the absence of typical species of this habitat (Biondi \& al., 2009).

Finally, for the purposes of proper management of the area, it would be desirable to adopt some specific conservation measures, in accordance with the Habitats Directive, aimed at re-naturalise or restore degraded or damaged habitats, especially the habitat of evergreen bush with Olea europaea and habitat of thermophilous shrubs with Euphorbia dendroides, as well as program of concrete measures for the eradication of invasive alien species, in particular Ailanthus altissima and Opuntia ficus-indica and as ultimate goal the control and containment of the Yellow-legged Gulls populations (Larus michahellis). It should however be emphasized that the solution of 
these problems is not easy to solve, not only from the technical viewpoint, but also taking into account that some of these plants, such as the indian-fig prickly pear, are perceived, by most stakeholders, as forming part of the Sicilian identity (Barbera \& al., 1992).
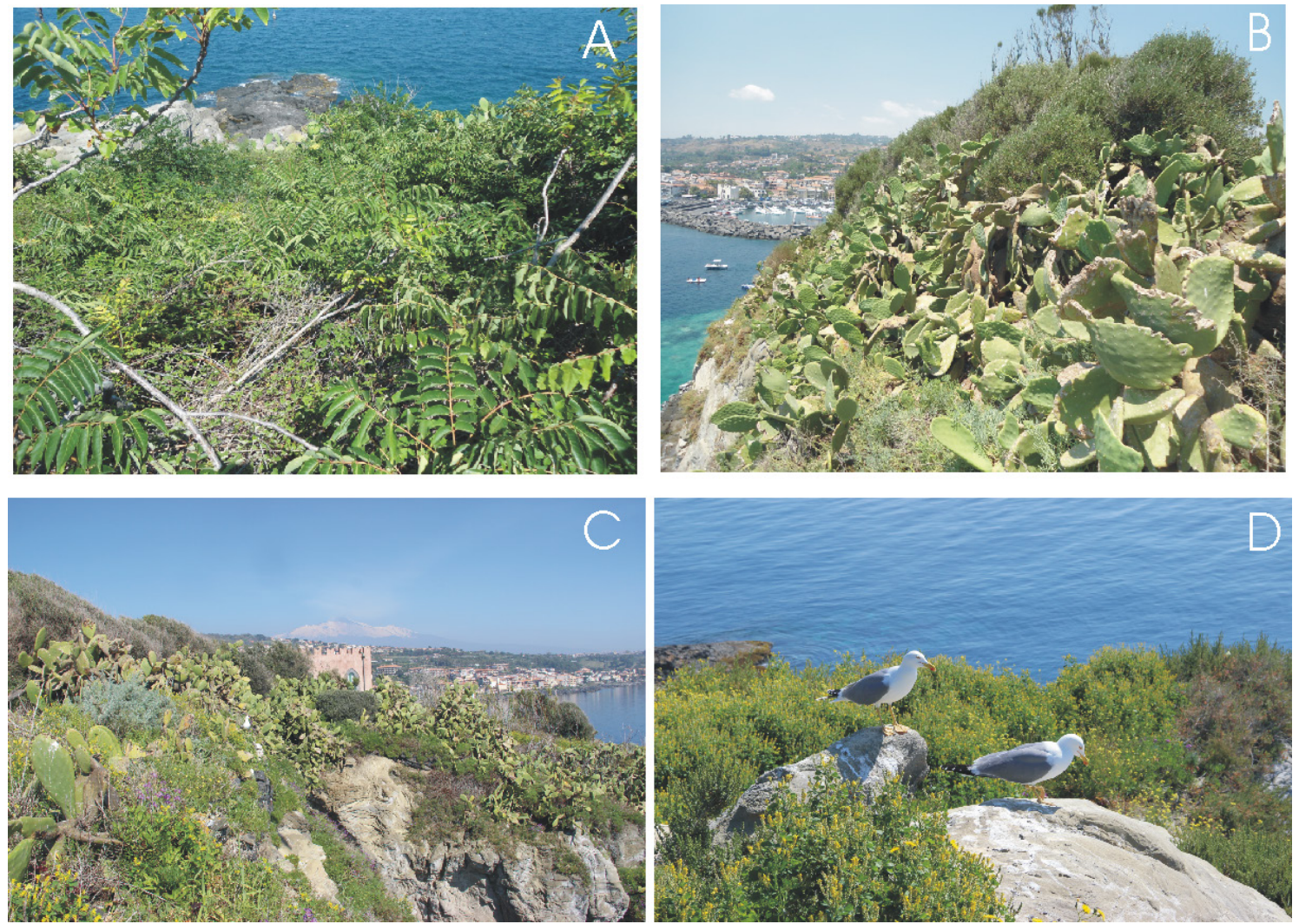

Figure10. Problematic species on Cyclops Islands. A. Ailanthus altissima; B-C.

Opuntia ficus-indica; D. Yellow-legged Gulls (Larus michahellis).

\section{Acknowledgements}

Research made with the financial contribution of "Regione Siciliana" to CUTGANA (protected area management). We are particularly grateful to Giovanni Signorello (Director of CUTGANA) and Agata Di Stefano (President of AMP Isole dei Ciclopi) for the suggestions and critical review of the manuscript, Domenico Catalano (Director of R.N.I., Isola Lachea e Faraglioni dei Ciclopi) and Mauro Contarino and Emanuele Puglia for the crucial logistic support.

\section{References}

Albo, G. 1959. La flora e la vegetazione delle isole intorno ai Capo Pachin. Boll. Ist. Bot. Univ. Catania 1(2): 88-108.

Bacchetta, G., Bagella, S., Biondi, E., Farris, E., Filigheddu, R. \& Mossa, L. 2003. Su alcune formazioni a Olea europea L. var. sylvestris Brot. della Sardegna. Fitosociologia 40(1): 49-53.

Barbera, G., Carimi, F. \& Inglese, P. 1992. Past and present role of the prickly-pear Opuntia ficus-indica (L.) Miller (Cactaceae) in the agriculture of Sicily. Econ. Bot. 46:10-20.

Bartolo, G., Brullo, S., Minissale, P. \& Spampinato G. 1990. Flora e vegetazione dell'isola di Lampedusa. Boll. Accad. Gioenia Sci. Nat. Catania 21(234): 119-255.

Bazan, G., Marino, P., Guarino, R., Domina, G. \& Schicchi, R. 2015. Bioclimatology and vegetation series in Sicily: a geostatistical approach. Ann. Bot. Fenn. 52(1-2):1-18. 
Biondi, E. 2007. Thoughts on the ecology and syntaxonomy of some vegetation typologies of the Mediterranean Coast. Fitosociol. 44 (1): 3-10.

Biondi, E., Allegrezza, M. \& Filigheddu, R. 1988. Su alcune formazioni ad Artemisia arborescens L. della Sardegna settentrionale. Boll. Soc. Sarda Sci. Nat. 26: 177-185.

Biondi, E., Blasi, C., Allegrezza, M., Anzellotti, I., Azzella, M.M., Carli, E., Casavecchia, S., Copiz, R., Del Vico, E., Facioni, L., Galdenzi, D., Gasparri, R., Lasen, C., Pesaresi, S., Poldini, L., Sburlino, G., Taffetani, F., Vagge, I., Zitti, S. \& Zivkovic, L. 2014. Plant communities of Italy: The Vegetation Prodrome. Plant Biosyst. 148(4): 728-814.

Biondi, E., Blasi, C., Burrascano, S., Casavecchia, S., Copiz, R., Del Vico, E., Galdenzi, D., Gigante, D., Lasen, C., Spampinato, G., Venanzoni, R. \& Zivkovic, L. 2009. Manuale Italiano di Interpretazione degli habitat della Direttiva 92/43/CEE-SBI, MATTM, DPN. Available at http://vnr.unipg.it/habitat/index.jsp.

Branca, S., Coltelli, M. \& Groppelli, G. 2001. Geological evolution of a complex basaltic stratovolcano: Mount Etna, Italy. Ital. J. Geosci. 130(3): 306-317.

Branca, S., Coltelli, M., Groppelli, G. \& Lentini, F. 2011. Geological map of Etna volcano, 1:50.000 scale. Ital. J. Geosci. 130 (3): 265-291.

Brullo, S., Giusso del Galdo, G., Guarino, R., Minissale, P., Sciandrello, S. \& Spampinato, G. 2013. Syntaxonomic survey of the class Pegano-Salsoletea in Italy. Plant Biosyst. 147(2): 472-492.

Brullo, S. \& De Marco, G. 1989. Anthyllidion barbae-jovis alleanza nuova dei Crithmo-Limonietea. Arch. Bot. Ital. 65(1/2): 109-120.

Brullo, S. \& Di Martino, A. 1974. Vegetazione dell'Isola Grande dello Stagnone (Marsala). Boll. Ist. Bot. Giardino Colon Palermo. 26: 15-62.

Brullo, S., Di Martino, A. \& Marcenò, C. 1977. La vegetazione di Pantelleria (studio fitosociologico). Pubbl. Ist. Bot. Univ. Catania, Catania. 110 pp.

Brullo, S. \& Giusso del Galdo, G. 2003. La classe Saginetea maritimae in Italia. Fitosociologia 40 (2): 29-41.

Brullo, S., Grillo, M. \& Guglielmo, A. 1998. Considerazioni fitogeografiche sulla flora iblea. Boll. Acc. Gioenia di Sci. Nat. Catania 29(352): 45-111.

Brullo, S. \& Marceno, C. 1983 Osservazioni fitosociologiche sull'Isola di Marettimo (Arcipelago delle Egadi). Boll. Accad. Gioenia Sci. Nat. Catania 15(320): 201-228.

Brullo, S. \& Siracusa, G. 1995. La flora dell'Isola di Linosa (Arcipelago delle Pelagie, Sicilia). Boll. Accad. Gioenia Sci. Nat. Catania 28(349): 471-497.

Catanzaro, F. 1965. Nuovo contributo alla flora dell'isola di Pantelleria. Webbia 20: 545-548.

Catanzaro, F. 1984. Contributo alla flora dell'Isola di Marettimo (Egadi). Naturalista Sic. 8(1-2): 27-34.

Catanzaro, F. 1992. Contributo alla flora dell'Isola di S. Pantaleo (Mozia) nelle Egadi (Sicilia occidentale). Atti Soc. Tosc. Sci. Nat. Mem. 98: 239-247.

Corsaro, R.A. \& Cristofolini, R. 2000. Subaqueous volcanism in the Etnean area: evidence for hydromagmatic activity and regional uplift inferred from the Castle Rock of Acicastello. J. Volcanol. Geoth. Res. 95: 209225.

De Beni, E., Branca, S., Coltelli, M., Groppelli, G. \& Wijbrans, J. 2011. 40Ar/39Ar isotopic dating of Etna volcanic succession. Ital. J. Geosci. 130(3): 292-305.

De Sanctis, C., Ronsisvalle, G.A. \& Siracusa, G. 1995. Indagine ecologico naturalistica della Riserva Integrale Isola Lachea. Giorn. Bot. Ital. 129(2): 100.

Di Benedetto, L. 1973. Flora di Alicudi (Isole Eolie). Arch. Bot. Biogeogr. Ital. 49: 135-162.

Di Martino, A. 1958. Nuovo contributo alla flora inedita delle Isole Pelagie. Lav. Ist. Bot. Giardino Colon. Palermo 16: 84-93.

Di Martino, A. 1962. Piante inedite di Pantelleria. Lav. Ist. Bot. Giardino Colon. Palermo 18: 72-79.

Di Martino, A. 1963. Flora e vegetazione dell'Isola di Pantelleria. Lav. Ist. Bot. Giardino Colon. Palermo 19: $87-243$

Di Martino, A. \& Perrone, C. 1970. Flora delle isole dello Stagnone (Marsala). I. Isola Grande. Lav. Ist. Bot. Giard. Colon. Palermo 24: 109-166.

Di Martino, A. \& Perrone, C. 1974. Flora delle isole dello Stagnone (Marsala). II. Isole di S.Pantaleo e S. Maria. Lav. Ist. Bot. Giard. Colon. Palermo 25: 71-102.

Di Martino, A. \& Trapani, S. 1964. Flora e vegetazione dell'Isola delle Femmine. Lav. Ist. Bot. Giard. Colon. Palermo 20: 121-159.

Di Martino, A. \& Trapani, S. 1967. Flora e vegetazione delle isole di Favignana e Levanzo nell'Arcipelago delle Egadi. I. Favignana. Lav. Ist. Bot. Giard. Colon. Palermo 22 (1965): 122-228. 
Di Martino, A. \& Trapani S. 1968. Flora delle isole di Favignana e Levanzo nell'Arcipelago delle Egadi. II. Levanzo. Lav. Ist. Bot. Giard. Colon. Palermo 23: 37-132.

Ferro, G. \& Furnari, F. 1968. Flora e vegetazione di Stromboli (Isole Eolie). Arch. Bot. Biogeogr. Ital. 12 (12): $21-45 ;(3): 59-85$.

Ferro, G. \& Furnari, F. 1970. Flora e vegetazione di Vulcano (Isole Eolie). Pubbl. Ist. Bot. Univ. Catania: 1-66. Fiori, A. 1923-1929. Nuova flora analitica d'Italia. Tipografia M. Ricci, Firenze.

Fiori, A. 1924. Nuova flora analitica d'Italia, 1(4-5). Tipografia M. Ricci, Firenze.

Francini, E. \& Messeri, A. 1956. L'Isola di Marettimo nelle Egadi e la sua vegetazione. Webbia 11(1955): 607-846.

Gianguzzi, L. 1999. Vegetazione e bioclimatologia dell'isola di Pantelleria (Canale di Sicilia). BraunBlanquetia 22: 1-70.

Gianguzzi, L., Scuderi, L. \& Pasta, S. 2006. La flora vascolare dell'Isola di Marettimo (Arcipelago delle Egadi, Sicilia occidentale): analisi fitogeografica ed aggiornamento. Webbia 61(2): 359-402.

Gristina, A.S. \& Marcenò, C. 2008. Gli indici di bioindicazione di Pignatti-Ellenberg nello studio floristicovegetazionale del promontorio di Capo Zafferano (Sicilia Nord-Occidentale). Naturalista sicil. 32(1-2): 61-96.

Janssen, J.A.M., Rodwell, J.S., García Criado, M., Gubbay, S., Haynes, T., Nieto, A., Sanders, N., Landucci, F., Loidi, J., Ssymank, A., Tahvanainen, T., Valderrabano, M., Acosta, A., Aronsson, M., Arts, G., Attorre, F., Bergmeier, E., Bijlsma, R.-J., Bioret, F., Biţă-Nicolae, C., Biurrun, I., Calix, M., Capelo, J., Čarni, A., Chytrý, M., Dengler, J., Dimopoulos, P., Essl, F., Gardfjell, H., Gigante, D., Giusso del Galdo, G., Hájek, M., Jansen, F., Jansen, J., Kapfer, J., Mickolajczak, A.,. Molina, J.A, Molnár, Z., Paternoster, D., Piernik, A., Poulin, B., Renaux, B., Schaminée, J.H.J., Šumberová, K., Toivonen, H., Tonteri, T., Tsiripidis, I., Tzonev, R. \& Valachovič, M. 2016. European Red List of Habitats. Part 2. Terrestrial and freshwater habitats. Publ. Off. Eur. Union, Luxembourg. 44 pp.

Kallimanis, A.S., Bergmeier, E., Panitsa, M., Georghiou, K., Delipetrou, P. \& Dimopoulos, P. 2010. Biogeographical determinants for total and endemic species richness in a continental archipelago. Biodivers. Conserv. 19: 1225-1235.

Lo Cascio, P. \& Pasta, S. 2012. Lampione, a paradigmatic case of Mediterranean island biodiversity. Biodiv. J. 3: 311-330.

Lojacono-Pojero, M. 1878. Le Isole Eolie e la loro vegetazione con enumerazione delle piante spontanee vascolari. Tip. G. Lorsnaider, Palermo. 140 pp.

Longhitano, N. 1983. Carta della vegetazione dell'Isola di Filicudi (Isole Eolie). Arch. Bot. Biogeogr. Ital. 58 (1-2): 89-105.

Mazzola, P., Geraci, A. \& Raimondo F.M. 2001. Endemismo e biodiversità floristica nelle Isole circumsiciliane. Biogeogr. 22: 45-63.

Médail, F. \& Quézel, P. 1999. Biodiversity Hotspots in the Mediterranean Basin: setting global conservation priorities. Conserv. Biol. 13: 1510-1513.

Minissale, P., Sciandrello, S. \& Spampinato, G. 2005. Analisi della biodiversità vegetale e relativa cartografia della Riserva Naturale Orientata Isola Bella e del territorio circostante (Taormina, ME, Sicilia). Quad. Bot. Amb. Appl. 16: 175-208.

Minissale, P. \& Sciandrello, S. 2017. Flora and habitats of Vendicari Islet ("Isola di Vendicari") in south east Sicily. Nat. Croat. 26: (in press.).

Mucina, L., Bültmann, H., Dierßen, K., Theurillat, J.-P., Raus, T., Čarni, A., Šumberová, K., Willner, W., Dengler, J., Gavilán, R.G., Chytrý, M., Hájek, M., Di Pietro, R., Iakushenko, D., Pallas, J., Daniëls, F.J.A., Bergmeier, E., Santos Guerra, A., Ermakov, N., Valachovič, M., Schaminée, J.H.J., Lysenko, T., Didukh, Y.P., Pignatti, S., Rodwell, J.S., Capelo, J., Weber, H.E., Solomeshch, A., Dimopoulos, P., Aguiar, C., Hennekens, S.M. \& Tichý, L. 2016. Vegetation of Europe: hierarchical floristic classification system of vascular plant, bryophyte, lichen, and algal communities. Appl. Veg. Sci. 19 (Suppl. 1): 3-264.

Musmarra, A. 1941. Florula delle Isole dei Ciclopi. Scuola Tipografica dell'Orfanotrofio maschile, Amatrice. 57 pp.

Nicotra, L. 1893. Nota sopra alcune piante della Sicilia. Malpighia 7: 82-90.

Pasta, S. 2001. Contributi alla conoscenza botanica delle isole minori circumsiciliane. I. Sintesi aggiornata delle conoscenze botaniche sull'Isola di Lampedusa finalizzata alla conservazione delle sue emergenze floristico-vegetazionali. Naturalista Sicil. 25: 19-70. 
Pasta, S. 2004. La conservazione delle emergenze botaniche nell'area costiera siciliana: il caso della R.N.O. "Isole dello Stganone di Marsala" (Trapani, Sicilia occidentale). Naturalista Sicil. 28: 243263.

Pasta, S. \& Lo Cascio, P. 2002. Contributi alla conoscenza botanica delle isole minori circumsiciliane. II. Note tassonomiche e geobotaniche sulla flora delle Isole Eolie. Naturalista Sicil. 26 (3-4): 131-145.

Pasta, S., Sciberras, A., Sciberras, J. \& Scuderi, L. 2014. Analysis of the vascular flora of four satellite islets of the Egadi Archipelago (W Sicily), with some notes on their vegetation and fauna. Biodiv. J. 5(1): 39-54.

Pignatti, S. 1982. Flora d'Italia 1-3. Edagricole, Bologna.

Podani, J. 2001. SYN-TAX 2000, computer program for multivariate analysis in ecology and taxonomy. Scientia Publishing, Budapest.

Pretto, F., Celesti-Grapow, L., Carli, E., Brundu, G. \& Blasi C. 2012. Determinants of non-native plant species richness and composition across small Mediterranean islands. Biol. Invasions 14: 2559-2572.

Rittman, A. 1973. Structure and evolution of Mount Etna. Philos. Trans. R. Soc. London 274: 5-16.

Rivas-Martínez, S. 1993. Bases para una nueva clasificacion bioclimatica de la tierra. Folia Bot. Matritensis 10: 1-23.

Rivas-Martínez, S, Penas, A. \& Diaz, TE. 2004. Biogeographic map of Europe. Cartogr. Serv.: León.

Romano, S., Tobia, G. \& Gianguzzi, L. 2006. Rassegna della flora vascolare dell'Isola di Levanzo (Arcipelago delle Egadi, Canale di Sicilia). Inf. Bot. Ital. 38: 481-502.

Sciandrello, S, D'Agostino, S. \& Minissale, P. 2013. Vegetation analysis of the Taormina Region in Sicily: a plant landscape characterized by geomorphology variability and both ancient and recent anthropogenic influences. Lazaroa 34: 151-190.

Sciandrello, S., D'Agostino, S. \& Minissale, P. 2014. The Vascular Flora of the Taormina Region (Peloritani Mountains - Northeast Sicily). Webbia 69: 301-324.

Sciandrello, S., Giusso Del Galdo, G.P. \& Minissale, P. 2016. Euphorbia hypericifolia L. (Euphorbiaceae), a new alien species for Italy. Webbia 71: 163-168.

Sciandrello, S., Guarino, R., Minissale, P. \& Spampinato, G. 2015. The endemic vascular flora of Peloritani Mountains (NE Sicily): Plant functional traits and phytogeographical relationships in the most isolated and fragmentary micro-plate of the Alpine orogeny. Plant Biosyst. 149(5): 838-854.

Siracusa, G. 1995. Florula delle Isole dei Ciclopi (Sicilia orientale). Boll. Accad. Gioenia Sci. Nat. Catania 28(349): 219-238.

Sommier, S. 1906. Le isole Pelagie, Lampedusa, Linosa, Lampione e la loro flora con un elenco completo dellepiante di Pantelleria. Boll. Reale Orto Bot. Giardino Colon. Palermo 5, 6, 7 appendici. Reprinted in 1908, Firenze.

Sommier, S. 1907. Piante inedite di Lampedusa e di Linosa. Boll. Soc. Bot. Ital. (1904): 245-247.

Sommier, S. 1922. Flora dell'isola di Pantelleria. Firenze.

Tanguy, J.C. 1978. Tholeiitic basalt magmatism of Mount Etna and its relations with the alkaline series. Contrib. Mineral. Petrol. 66, 51-67.

Troìa, A. 1998. Contributo alla conoscenza della flora delle Isole Eolie (Sicilia). Inform. Bot. Ital. 29 (2-3): 262-266.

Tutin, T.G., Heywood, V.H., Burges, N.A., Moore, D.M., Valentine, D.H., Walters, S.M. \& Webb, D.A., editors. 1964-1980. Flora Europaea (1-5). Cambridge Univ. Press, Cambridge.

Van der Maarel, E. 1979. Transformation of cover-abundance values in phytosociology and its effects on community similarità. Vegetatio 39: 97-114.

Zodda, G. 1910. Briofite sicule (contribuzione quarta). Malpighia 24: 258-277.

Wezel, F.C. 1967. I terreni quaternari del substrato dell'Etna. Atti Accad. Gioenia Sci. Nat. Catania 6: 271-283.

\section{Appendix 1}

Floristic list. Abbreviations are: Fr.: Frequency; Is. Lac.: Isola Lachea; Al.: S. Alonga; Gr.: Faraglione Grande; F. Mez.: Faraglione Di Mezzo; Pic.: Faraglione Piccolo; * Introduced plant species; : presence in each islet; T.: total number of taxa for each islet. 


\begin{tabular}{|c|c|c|c|c|c|c|c|c|c|c|}
\hline $\mathrm{N}$. & Family & Species & Chorology & Life form & Fr. & Lac. & Al. & Gr. & Mez. & Pic. \\
\hline 1 & Acanthaceae & Acanthus mollis L. & O Med. & H scap & $\mathrm{C}$ & $\mathrm{p}$ & & & & \\
\hline 2 & Aizoaceae & Mesembryanthemum nodiflorum $\mathrm{L}$. & Med.-Trop. & T scap & $\mathrm{R}$ & $\mathrm{p}$ & & & & \\
\hline 3 & Alliaceae & Allium commutatum Guss. & Med. & G bulb & $\mathrm{NC}$ & $\mathrm{p}$ & & $\mathrm{p}$ & $\mathrm{p}$ & $\mathrm{p}$ \\
\hline 4 & Alliaceae & Allium ampeloprasum L. & Med. & G bulb & C & $\mathrm{p}$ & & $\mathrm{p}$ & & \\
\hline 5 & Amaryllidaceae & *Amaryllis belladonna $\mathrm{L}$. & Sud-Africa & G bulb & & $\mathrm{p}$ & & & & \\
\hline 6 & Apiaceae & Crithmum maritimum L. & Med.-Atl. & Ch suffr & $\mathrm{NC}$ & $\mathrm{p}$ & & $\mathrm{p}$ & & $\mathrm{p}$ \\
\hline 7 & Apiaceae & Daucus carota L. subsp. carota & Euro-Med. & $\mathrm{H}$ bien & $\mathrm{NC}$ & $\mathrm{p}$ & & $\mathrm{p}$ & & \\
\hline 8 & Apiaceae & Daucus gingidium L. & C Med. & H bien & $\mathrm{R}$ & $\mathrm{p}$ & & & & \\
\hline 9 & Apiaceae & Ferula communis L. & Med. & H scap & $\mathrm{NC}$ & $\mathrm{p}$ & & $\mathrm{p}$ & & \\
\hline 10 & Apiaceae & Thapsia garganica $\mathrm{L}$. & Med. & H scap & $\mathrm{NC}$ & $\mathrm{p}$ & & $\mathrm{p}$ & & \\
\hline 11 & Apocynaceae & *Nerium oleander L. & Med. & P caesp & $\mathrm{NC}$ & $\mathrm{p}$ & & & & \\
\hline 12 & Araceae & Arisarum vulgare Targ.-Tozz. & Med. & G rhiz & $\mathrm{NC}$ & $\mathrm{p}$ & & $\mathrm{p}$ & & \\
\hline 13 & Asparagaceae & Asparagus acutifolius L. & Med. & $\mathrm{NP}$ & $\mathrm{NC}$ & $\mathrm{p}$ & & $\mathrm{p}$ & $\mathrm{p}$ & \\
\hline 14 & Asparagaceae & Asparagus albus $\mathrm{L}$. & O Med. & $\mathrm{NP}$ & $\mathrm{NC}$ & $\mathrm{p}$ & & $\mathrm{p}$ & & \\
\hline 15 & Asteraceae & Artemisia arborescens (Vaill.) L. & Med. & $\mathrm{NP}$ & $\mathrm{C}$ & $\mathrm{p}$ & & $\mathrm{p}$ & & \\
\hline 16 & Asteraceae & $\begin{array}{l}\text { Carlina hispanica Lam. subsp. globosa } \\
\text { (Arcang.) Meusel \& Kästner }\end{array}$ & End. It.-sic. & H scap & $\mathrm{NC}$ & $\mathrm{p}$ & & p & & \\
\hline 17 & Asteraceae & Dittrichia viscosa (L.) Greuter & O Med. & H scap & $\mathrm{C}$ & $\mathrm{p}$ & & & & \\
\hline 18 & Asteraceae & Erigeron bonariensis hort. ex Link & Avv. & T scap & C & $\mathrm{p}$ & & & & \\
\hline 19 & Asteraceae & Erigeron canadensis L. & Cosmop. & T scap & C & $\mathrm{p}$ & & & & \\
\hline 20 & Asteraceae & Galactites elegans (All.) Soldano & Med. & $\mathrm{H}$ bien & C & $\mathrm{p}$ & & $\mathrm{p}$ & & \\
\hline 21 & Asteraceae & Glebionis coronaria (L.) Spach & Med. & T scap & C & $\mathrm{p}$ & & & & \\
\hline 22 & Asteraceae & Limbarda chrithmoides (L.) Dumort. & Med.-Atl. & Ch suffr & $\mathrm{R}$ & $\mathrm{p}$ & & & & \\
\hline 23 & Asteraceae & Reichardia picroides (L.) Roth & Med. & H scap & $\mathrm{NC}$ & $\mathrm{p}$ & & $\mathrm{p}$ & $\mathrm{p}$ & \\
\hline 24 & Asteraceae & Sonchus asper (L.) Hill & Cosmop. & T scap & C & $\mathrm{p}$ & & $\mathrm{p}$ & & \\
\hline 25 & Asteraceae & Sonchus bulbosus (L.) Kilian \& Greuter & Med. & G bulb & $\mathrm{NC}$ & $\mathrm{p}$ & & & & \\
\hline 26 & Asteraceae & Sonchus oleraceus L. & Cosmop. & T scap & C & $\mathrm{p}$ & & $\mathrm{p}$ & $\mathrm{p}$ & \\
\hline 27 & Asteraceae & $\begin{array}{l}\text { Urospermum picroides (L.) } \\
\text { F. W. Schmidt }\end{array}$ & Med. & T scap & C & $\mathrm{p}$ & & $\mathrm{p}$ & & \\
\hline 28 & Asteraceae & $\begin{array}{l}\text { Symphyotrichum squamatum (Spreng.) } \\
\text { G. L. Nesom }\end{array}$ & Nat. & H scap. & C & p & & & & \\
\hline 29 & Asteraceae & Pulicaria dysenterica (L.) Bernh. & Euro-Med. & H scap & $\mathrm{R}$ & $\mathrm{p}$ & & & & \\
\hline 30 & Asteraceae & Helminthotheca echioides (L.) Holub & Med. & T scap & $\mathrm{R}$ & $\mathrm{p}$ & & & & \\
\hline 31 & Boraginaceae & Heliotropium europaeum L. & \begin{tabular}{|l} 
Euro-Med.- \\
Iran.-Tur
\end{tabular} & T scap & $\mathrm{NC}$ & $\mathrm{p}$ & & $\mathrm{p}$ & & \\
\hline 32 & Brassicaceae & Brassica fruticulosa Cirillo & O Med. & H scap & C & $\mathrm{p}$ & & $\mathrm{p}$ & & \\
\hline 33 & Brassicaceae & $\begin{array}{l}\text { Matthiola incana (L.) R. Br. subsp. } \\
\text { incana }\end{array}$ & NO-Med. & Ch suffr & $\mathrm{NC}$ & $\mathrm{p}$ & & $\mathrm{p}$ & $\mathrm{p}$ & $\mathrm{p}$ \\
\hline 34 & Brassicaceae & Sisymbrium polyceratium L. & Med. & T scap & $\mathrm{R}$ & $\mathrm{p}$ & & & & \\
\hline 35 & Cactaceae & *Opuntia ficus-indica (L.) Mill. & Nat. & $\mathrm{P}$ succ & $\mathrm{C}$ & $\mathrm{p}$ & & & & \\
\hline 36 & Capparidaceae & Capparis orientalis Veill. & Med. & Ch suffr & $\mathrm{NC}$ & $\mathrm{p}$ & & $\mathrm{p}$ & $\mathrm{p}$ & \\
\hline 37 & Capparidaceae & Capparis spinosa L. & $\begin{array}{l}\text { Med.-Iran.- } \\
\text { Tur. }\end{array}$ & Ch suffr & $\mathrm{R}$ & $\mathrm{p}$ & & & & \\
\hline 38 & Caryophyllaceae & Cerastium pumilum Curtis & Euro-Med. & Tscap & $\mathrm{NC}$ & $\mathrm{p}$ & & & & \\
\hline 39 & Caryophyllaceae & $\begin{array}{l}\text { Polycarpon tetraphyllum subsp. } \\
\text { diphyllum (Cav.) O. Bolòs \& Font Quer }\end{array}$ & Med. & T scap & $\mathrm{NC}$ & $\mathrm{p}$ & & & & \\
\hline 40 & Caryophyllaceae & Sagina maritima G. Don & Med.-Atl. & T scap & $\mathrm{NC}$ & $\mathrm{p}$ & & $\mathrm{p}$ & & \\
\hline 41 & Caryophyllaceae & $\begin{array}{l}\text { Silene vulgaris (Moench) Garcke subsp. } \\
\text { tenoreana (Colla) Soldano \& F. Conti }\end{array}$ & End. sic. & H scap & C & $\mathrm{p}$ & & $\mathrm{p}$ & $\mathrm{p}$ & \\
\hline 42 & Caryophyllaceae & Spergularia bocconi (Scheele) Graebn. & Paleotemp. & T scap & $\mathrm{NC}$ & $\mathrm{p}$ & & $\mathrm{p}$ & & \\
\hline 43 & Caryophyllaceae & Spergularia salina J. \& C. Presl & Paleotemp. & T scap & $\mathrm{NC}$ & & & $\mathrm{p}$ & & \\
\hline 44 & Casuarinaceae & *Casuarina equisetifolia $\mathrm{L}$. & Australia & P scap & $\mathrm{NC}$ & $\mathrm{p}$ & & & & \\
\hline 45 & Chenopodiaceae & Atriplex halimus L. & Med. & P caesp & $\mathrm{R}$ & $\mathrm{p}$ & & $\mathrm{p}$ & & \\
\hline 46 & Chenopodiaceae & Chenopodium album $\mathrm{L}$. & Cosmop. & T scap & C & $\mathrm{p}$ & & $\mathrm{p}$ & $\mathrm{p}$ & \\
\hline 47 & Chenopodiaceae & Suaeda vera J. F. Gmelin & Med.-Atl. & NP casp & C & $\mathrm{p}$ & $\mathrm{p}$ & $\mathrm{p}$ & $\mathrm{p}$ & $\mathrm{p}$ \\
\hline 48 & Convolvulaceae & Cuscuta epithymum L. subsp. epithymum & Paleotemp. & T par & $\mathrm{NC}$ & $\mathrm{p}$ & & & & \\
\hline 49 & Crassulaceae & Sedum rubens L. & Euro-Med. & T scap & $\mathrm{NC}$ & & & $\mathrm{p}$ & & \\
\hline 50 & Crassulaceae & Umbilicus rupestris (Salisb.) Dandy & Med.-Trop. & G bulb & $\mathrm{NC}$ & $\mathrm{p}$ & & & & \\
\hline 51 & Crassulaceae & Umbilicus horizontalis (Guss.) DC. & Med.-Trop. & G bulb & $\mathrm{NC}$ & & & $\mathrm{p}$ & & \\
\hline 52 & Cyperaceae & Cyperus rotundus $\mathrm{L}$. & Med.-Trop. & G rhiz & C & $\mathrm{p}$ & & & & \\
\hline 53 & Euphorbiaceae & Mercurialis annиa L. & Paleotemp. & T scap & C & $\mathrm{p}$ & & & & \\
\hline
\end{tabular}




\begin{tabular}{|c|c|c|c|c|c|c|c|c|c|c|}
\hline $\mathrm{N}$. & Family & Species & Chorology & Life form & Fr. & Lac. & Al. & Gr. & Mez. & Pic. \\
\hline 54 & Fabaceae & Lotus cytisoides L. & Med. & Ch suffr & $\mathrm{NC}$ & $\mathrm{p}$ & & $\mathrm{p}$ & $\mathrm{p}$ & $\mathrm{p}$ \\
\hline 55 & Fabaceae & Medicago truncatula Gaertn. & Med.-Atl. & T scap & $\mathrm{NC}$ & $\mathrm{p}$ & & & & \\
\hline 56 & Fabaceae & Melilotus italicus (L.) Lam. & Med. & T scap & $\mathrm{NC}$ & $\mathrm{p}$ & & $\mathrm{p}$ & & \\
\hline 57 & Fabaceae & Melilotus sulcatus Desf. & Med. & T scap & C & $\mathrm{p}$ & & & & \\
\hline 58 & Fabaceae & *Robinia pseudacacia L. & Nat. & P caesp & $\mathrm{NC}$ & $\mathrm{p}$ & & & & \\
\hline 59 & Fabaceae & *Spartium junceum L. & Med. & P caesp & $\mathrm{NC}$ & $\mathrm{p}$ & & & & \\
\hline 60 & Fabaceae & Trifolium scabrum L. & Med. & T rept & $\mathrm{NC}$ & $\mathrm{p}$ & & $\mathrm{p}$ & & \\
\hline 61 & Frankeniaceae & Frankenia pulverulenta $\mathrm{L}$. & $\begin{array}{l}\text { Med.-Iran.- } \\
\text { Tur. }\end{array}$ & T scap & $\mathrm{R}$ & $\mathrm{p}$ & & & & \\
\hline 62 & Geraniaceae & Erodium malacoides (L.) L'Hér. & Med. & T scap & C & $\mathrm{p}$ & & & & \\
\hline 63 & Lamiaceae & Prasium majus L. & Med. & Ch frut & $\mathrm{R}$ & $\mathrm{p}$ & & & & \\
\hline 64 & Lauraceae & *Laurus nobilis L. & Med.-Atl. & P caesp & $\mathrm{NC}$ & $\mathrm{p}$ & & & & \\
\hline 65 & Malvaceae & Malva sylvestris L. & Euro-Med. & H scap & $\mathrm{C}$ & $\mathrm{p}$ & & & & \\
\hline 66 & Moraceae & Ficus carica L. & N Med. & P scap & $\mathrm{NC}$ & $\mathrm{p}$ & & $\mathrm{p}$ & & \\
\hline 67 & Oleaceae & $\begin{array}{l}\text { Olea europaea var. sylvestris } \\
\text { (Mill.) Lehr }\end{array}$ & Med. & P caesp & $\mathrm{NC}$ & $\mathrm{p}$ & & $\mathrm{p}$ & & \\
\hline 68 & Oxalidaceae & Oxalis pes-caprae L. & Nat. & G bulb & $\mathrm{C}$ & $\mathrm{p}$ & & & & \\
\hline 69 & Papaveraceae & Fumaria capreolata L. & Euro-Med. & T scap & $\mathrm{C}$ & $\mathrm{p}$ & & & & \\
\hline 70 & Papaveraceae & Fumaria flabellata Gasparr. & Med. & T scap & $\mathrm{NC}$ & $\mathrm{p}$ & & & & \\
\hline 71 & Pittosporaceae & *Pittosporum tobira (Thunb.) W. T. Aiton & Med. & T rept & $\mathrm{NC}$ & $\mathrm{p}$ & & & & \\
\hline 72 & Plantaginaceae & Plantago coronopus L. & Paleotemp. & T scap & $\mathrm{NC}$ & $\mathrm{p}$ & & $\mathrm{p}$ & & \\
\hline 73 & Plantaginaceae & Plantago lagopus L. & Med. & T scap & C & & & $\mathrm{p}$ & & \\
\hline 74 & Poaceae & Anisantha madritensis (L.) Nevski & Med.-Atl. & T scap & C & $\mathrm{p}$ & & $\mathrm{p}$ & & \\
\hline 75 & Poaceae & *Arundo donax L. & Med. & G rhiz & $\mathrm{NC}$ & $\mathrm{p}$ & & & & \\
\hline 76 & Poaceae & $\begin{array}{l}\text { Catapodium balearicum (Willk.) } \\
\text { H. Scholz }\end{array}$ & Med. & T scap & $\mathrm{NC}$ & $\mathrm{p}$ & & $\mathrm{p}$ & & \\
\hline 77 & Poaceae & Catapodium rigidum (L.) C. E. Hubb. & \begin{tabular}{|l} 
Euro-Med.- \\
Iran.-Tur
\end{tabular} & T scap & C & $\mathrm{p}$ & & & & \\
\hline 78 & Poaceae & $\begin{array}{l}\text { Dactylis glomerata subsp. hispanica } \\
\text { (Roth) Nyman }\end{array}$ & Med. & H caesp & $\mathrm{NC}$ & $\mathrm{p}$ & & $\mathrm{p}$ & $\mathrm{p}$ & \\
\hline 79 & Poaceae & $\begin{array}{l}\text { Hordeum murinum L. subsp. leporinum } \\
\text { (Link) Arcang. }\end{array}$ & Euro-Med & T scap & $\mathrm{C}$ & & & $\mathrm{p}$ & & \\
\hline 80 & Poaceae & Lagurus ovatus L. subsp. ovatus & Med. & T scap & C & $\mathrm{p}$ & & $\mathrm{p}$ & & \\
\hline 81 & Poaceae & Lolium rigidum Gaudin & $\begin{array}{l}\text { Med.-Iran.- } \\
\text { Tur. }\end{array}$ & T scap & C & $\mathrm{p}$ & & $\mathrm{p}$ & & \\
\hline 82 & Poaceae & Parapholis incurva (L.) C. E. Hubb. & Med.-Atl. & T scap & $\mathrm{NC}$ & $\mathrm{p}$ & & $\mathrm{p}$ & & \\
\hline 83 & Poaceae & $\begin{array}{l}\text { Piptatherum miliaceum (L.) Coss. subsp. } \\
\text { miliaceum }\end{array}$ & Med.-Atl. & H caesp & $\mathrm{NC}$ & $\mathrm{p}$ & & & & \\
\hline 84 & Poaceae & Rostraria cristata (L.) Tzvelev & $\begin{array}{l}\text { Med.-Iran.- } \\
\text { Tur. }\end{array}$ & T scap & C & $\mathrm{p}$ & & & & \\
\hline 85 & Poaceae & Trachynia distachya $(\mathrm{L}$.$) Link$ & $\begin{array}{l}\text { Med.-Iran.- } \\
\text { Tur. }\end{array}$ & T scap & $\mathrm{C}$ & $\mathrm{p}$ & & $\mathrm{p}$ & & \\
\hline 86 & Poaceae & Vulpia ciliata Dumort. & Med. & T caesp & $\mathrm{C}$ & $\mathrm{p}$ & & & & \\
\hline 87 & Poaceae & Vulpia geniculata (L.) Link & O Med. & T caesp & C & $\mathrm{p}$ & & & & \\
\hline 88 & Poaceae & $\begin{array}{l}\text { Digitaria sanguinalis (L.) Scop. subsp. } \\
\text { sanguinalis }\end{array}$ & Boreo-Trop. & T scap & $\mathrm{R}$ & & & $\mathrm{p}$ & & \\
\hline 89 & Poaceae & Avena barbata Pott ex Link & Cosmop. & T scap & $\mathrm{C}$ & $\mathrm{p}$ & & $\mathrm{p}$ & & \\
\hline 90 & Poaceae & Cynodon dactylon (L.) Pers. & Boreo-Trop. & G rhiz & $\mathrm{NC}$ & $\mathrm{p}$ & & & & \\
\hline 91 & Poaceae & $\begin{array}{l}\text { Gastridium ventricosum (Gouan) } \\
\text { Schinz \& Thell. }\end{array}$ & Med. & T scap & $\mathrm{NC}$ & $\mathrm{p}$ & & & & \\
\hline 92 & Portulacaceae & Portulaca oleracea L. subsp. oleracea & Boreo-Trop. & T scap & $\mathrm{C}$ & $\mathrm{p}$ & & $\mathrm{p}$ & & \\
\hline 93 & Primulaceae & Anagallis arvensis $\mathrm{L}$. & Boreo-Trop. & T rept & C & $\mathrm{p}$ & & & & \\
\hline 94 & Primulaceae & Anagallis foemina Mill. & Boreo-Trop. & T rept & $\mathrm{C}$ & $\mathrm{p}$ & & & & \\
\hline 95 & Rosaceae & Rubus ulmifolius Schott & Euro-Med. & $\mathrm{NP}$ & $\mathrm{NC}$ & $\mathrm{p}$ & & & & \\
\hline 96 & Rubiaceae & Galium aparine L. subsp. aparine & Paleotemp. & T scap & $\mathrm{NC}$ & $\mathrm{p}$ & & & & \\
\hline 97 & Rubiaceae & Valantia muralis L. & End. sic. & T scap & $\mathrm{C}$ & $\mathrm{p}$ & & & & \\
\hline 98 & Simaroubaceae & *Ailanthus altissima (Mill.) Swingle & Nat. & P scap & C & $\mathrm{p}$ & & & & \\
\hline 99 & Solanaceae & Hyoscyamus albus L. & Med. & T scap & $\mathrm{C}$ & $\mathrm{p}$ & & $\mathrm{p}$ & $\mathrm{p}$ & $\mathrm{p}$ \\
\hline 100 & Solanaceae & Solanum nigrum L. & Boreo-Trop. & T scap & $\mathrm{C}$ & $\mathrm{p}$ & & & & \\
\hline 101 & Urticaceae & Parietaria lusitanica L. & Med. & T rept & C & $\mathrm{p}$ & & & & \\
\hline \multirow[t]{2}{*}{102} & Urticaceae & Urtica membranacea Poir. & Med. & T scap & $\mathrm{C}$ & $\mathrm{p}$ & & & & \\
\hline & & & & & & T. 96 & T. 1 & T. 48 & T. 12 & T. 6 \\
\hline
\end{tabular}




\section{Appendix 2}

Syntaxonomic scheme

CRITHMO-STATICETEA Br.-Bl. in Br.-Bl. et al. 1952

Crithmo maritimi-Staticetalia Molinier 1934

Crithmo maritimi-Staticion Molinier 1934

Crithmetum maritimi Béguinot 1941

Helichrysetalia italici Biondi et Géhu in Géhu et Biondi 1994

Anthyllidion barbae-jovis Brullo \& De Marco 1989

Matthiola incana subsp. incana comm.

Pegano harmalae-Salsoletea Vermiculatae Br-Bl \& O.Bolòs 1958

Salsolo vermiculatae-Peganetalia harmalae Br.-B1. \& O. Bolòs 1954

Atriplici halimi-Suaedion verae Gehu et al. ex Bergmeier et Dimopoulos 2003 Atriplici halimi-Suaedetum verae Biondi 1988 nom. inv. propos. (Suaedo veraeAtriplicetum halimi Biondi 1988)

Artemision arborescentis Géhu et al. 1986

Atriplici halimi-Artemisietum arborescentis Biondi 1988

SAGINETEA MARItimaE Westhoff, Van Leeuwen \& Adriani 1962

Frankenietalia pulverulentae Rivas-Martínez ex Castroviejo \& Porta 1976

Frankenion pulverulentae Rivas-Martínez ex Castroviejo \& Porta 1976

Trifolio scabri-Catapodietum balearici Brullo et Giusso del Galdo 2003

Parapholido incurvae-Spergularietum bocconei Brullo, Scelsi \& Spampinato 2001 Mesembryanthemum nodiflorum comm.

Quercetea ILICIS Br.-Bl. ex A. Bolòs et O. de Bolòs in A. Bolòs y Vayreda 1950

Pistacio lentisci-Rhamnetalia alaterni Rivas-Mart. 1975

Oleo-Ceratonion siliquae Br.-Bl. ex Guinochet et Drouineau 1944

Asparago acutifolii-Oleetum sylvestris Bacchetta et al. 2003

CRATAEGO-PRUNETEA Tx. 1962

Pyro spinosae-Rubetalia ulmifolii Biondi, Blasi et Casavecchia in Biondi et al. 2014

Pruno spinosae-Rubion ulmifolii O. de Bolòs 1954

Rubus ulmifolius comm.

Chenopodietea Br.-Bl. in Br.-Bl. et al. 1952

Chenopodietalia Br.-B1. in Br.-B1. et al. 1936

Allion triquetri O. Bolòs 1967

Acanthus mollis comm.

Brometalia rubenti-tectorum (Rivas Goday et Rivas-Mart. 1973) Rivas-Mart. et Izco 1977

Echio-Galactition tomentosae O. Bolòs \& Molinier 1969

Galactites elegans comm.

Vulpia geniculata comm. 
